\title{
Trophic environments influence size at metamorphosis and recruitment performance of Pacific oysters
}

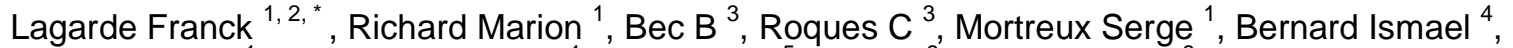 \\ Chiantella Claude ${ }^{1}$, Messiaen Gregory ${ }^{1}$, Nadalini $\mathrm{Jb}^{5}$, Hori $\mathrm{M}^{6}{ }^{6}$, Hamaguchi $\mathrm{M}^{6}$, Pouvreau Stephane ${ }^{7}$, \\ Roque D'Orbcastel Emmanuelle ${ }^{1}$, Tremblay R ${ }^{5}$
}

${ }^{1}$ MARBEC Ifremer, IRD, Univ. Montpellier, CNRS, 34200 Sète, France

2 Sorbonne Université, Collège Doctoral, 75005 Paris, France

${ }^{3}$ MARBEC Ifremer, IRD, Univ. Montpellier, CNRS, 34095 Montpellier, France

${ }^{4}$ Eureka Modélisation, 22740 Lézardrieux, France

${ }^{5}$ Université du Québec A Rimouski, Québec 65L 2Z9, Canada

6 JFREA, NRIFEIS, 739-0452 Hiroshima, Japan

${ }^{7}$ LEMAR Ifremer, IRD, CNRS, UBO, 29280 Plouzané, France

* Corresponding author : Franck Lagarde, email address : franck.lagarde@ifremer.fr

\begin{abstract}
:
Reproduction and recruitment of benthic invertebrates are influenced by the climate and by the ecological structure of marine ecosystems, along with local anthropogenic pressures such as eutrophication or oligotrophication. Using the Pacific oyster Crassostrea gigas as a biological model, we tested the hypothesis that the variability in prodissoconch II (PII) size (i.e. size at metamorphosis) depends on ecological functioning. Settlement and recruitment were assessed at 5 sampling sites on the French Mediterranean shellfish farmed Thau lagoon during the main summer recruitment events in 3 consecutive years (2012-2014). Hydrobiological and planktonic analyses were conducted at 3 sampling sites. Our results showed that recruitment was extremely heterogeneous, ranging from 0 to $260 \pm 27$ SE ind. dm-2 throughout the ecosystem and was linked with variability in PII size, which ranged from 180 to $296 \mu \mathrm{m}$. The annual temporal pattern of PII sizes appeared to be controlled by temperature during the settlement period, whereas the spatial pattern depended on phytoplankton biomass and on the trophic functioning of the ecosystem. Smaller PII sizes were significantly correlated with the highest phytoplankton biomass, while larger PII sizes were positively correlated with mixotrophic cryptophyte abundance. We found an inverse relationship between PII size and survival after metamorphosis, showing that recruitment success was associated with smaller PII sizes. Regional climate conditions and local trophic functioning appear to be key factors in metamorphosis and consequently contribute to recruitment heterogeneity. Further studies should be performed in other ecosystems following an oligotrophication trajectory to generalize this result.
\end{abstract}

Keywords : Larval ecology, Recruitment, Prodissoconch II, Crassostrea gigas, Oligotrophication, Cryptophytes, Thau lagoon 


\section{INTRODUCTION}

While the impacts of eutrophication were a preoccupation in the 2000s (Nixon 1995, De Jonge \& Elliott 2001, Smith \& Schindler 2009), increased demand for the recovery of ecosystem services (Bullock et al. 2011) and good environmental status (Vethaak et al. 2017) have raised new questions about the repercussions of oligotrophication on community structure (Lie et al. 2011, Saeck et al. 2013) and about the function of some coastal ecosystems (Jeppesen et al. 1998, 2005, Duarte et al. 2009, Yanagi 2015). French Mediterranean lagoons (Collos et al. 2009, Leruste et al. 2016), like some Japanese shellfish farmed estuaries and bays (Yanagi 2015), are subject to oligotrophication processes caused by wastewater management. A decrease in nutrient inputs into Mediterranean lagoons led to a decrease in phytoplankton biomass and hence to a shift in the structure of phytoplankton community from diatoms, cryptophytes and green algae to mixotrophic dinophytes (Gowen et al. 2015, Leruste et al. 2016), toxic dinoflagellates and picocyanobacteria (Collos et al. 2009). Changes in the ecological structure or ecological function of phytoplankton communities may have consequences for the food web (Alvarez-Cobelas \& Rojo 2000, Cloern 2001). A reduction in phytoplankton biomass could cause major problems and could jeopardize the carrying capacities of coastal ecosystems that are exploited for shellfish farming, like in the Thau lagoon and hence their sustainability (Dame 2012).

We suggest that these impacts may be accentuated in the first development stages of bivalves, as larvae and newly settled juveniles have been widely shown to be the most susceptible to stressful conditions (Qiu et al. 2002, Rayssac et al. 2010, Jenewein \& Gosselin 2013). Their susceptibility can be expressed in many ways, but is usually reflected in growth and survival. In the Pacific oyster Crassostrea gigas, newly referred to as Magallana gigas, a planktotrophic stage corresponds to a pelagic free-swimming period during which the veliger larvae feed, grow and 
disperse via water currents generally for a period of between two and four weeks (Kennish et al. 1995, Bhaud 2000). Near the end of its planktonic period, the advanced veliger develop competent characteristics, like feet for territorial prospecting behavior (pediveliger stage) and become able to settle (Pechenik \& Heyman 1987, Hadfield et al. 2001) followed by metamorphosis, when they are transformed into post larval benthic mollusks (Zardus \& Martel 2002, Bishop et al. 2006, Pechenik 2006). In marine invertebrates, metamorphosis integrated early ontogenic factors and environmental selection (Bishop et al. 2006) and is generally achieved in oysters within 1-3 days (Baker \& Mann 1998). In bivalves, metamorphosis is defined as the morphological change associated with the attachment of the individual to a substrate and the secretion of a dissoconch shell (Bayne 1976). Metamorphosis involves four stages, 1) attachment to the substrate by the foot, 2) a change in the particle collecting structure from velum to completely developed heterorhabdic gills (Cannuel \& Beninger 2006), 3) shell growth beyond the prodissoconch 4) loss of all larval organs to complete metamorphosis into a fully developed juvenile (Baker \& Mann 1994). Metamorphosis is triggered by chemical and/or physical cues when conditions allowing the morphological transformation are favorable, e.g. a suitable habitat, thermal and hyaline requirements, the quantity and quality of available food (Pechenik 1990, Bishop et al. 2006, Toupoint et al. 2012). The lack of settlement/metamorphosis cues may delay metamorphosis, thereby prolonging the larval stage until a suitable environment is found (Coon et al. 1990, Pechenik 2006). Thus, size at metamorphosis estimated by the prodissoconch II (PII) measurements can be highly variable (Coon et al. 1990, Martel et al. 1995, 2014). Although significant research has been conducted on Mytilus edulis and suggests that trophic factors affect settlement/size at metamorphosis (Martel et al. 2014), to date, no study has been conducted on oysters, one of the most economically important groups of invertebrates. The 
purpose of our study was thus to test the hypothesis that the size of $C$. gigas at metamorphosis is linked to specific environmental/trophic conditions that may affect the success of subsequent recruitment. The Thau lagoon was selected to test this hypothesis because of its high temporal and spatial ecological heterogeneity that affect oyster recruitment (Lagarde et al. 2017).

The specific objective of this study was to characterize the spatial and temporal variability of oyster spat recruitment to (i) test the existence of variation of PII size in the Thau lagoon, (ii) evaluate the relationship between this variation and environmental and/or trophic conditions and (iii) assess its impact on recruitment success. The originality of this study is the simultaneous monitoring of larvae, juveniles (abundance and survival), size at metamorphosis, hydrobiological conditions and planktonic characteristics in the same species in three different years (2012-2014) at five different sampling sites.

\section{MATERIALS AND METHODS}

\section{Thau lagoon and sampling sites}

The Thau lagoon is the largest nanotidal lagoon in the Occitanie region (formerly known as Languedoc-Roussillon) in southern France. It covers an area of 7,500 ha (19 km $\times 4.5 \mathrm{~km})$ orientated along a north-east / southwest axis and has a mean depth of $3.5 \mathrm{~m}$. Seawater from the Mediterranean Sea enters through narrow channels. Five sampling sites were monitored to assess pre-settled oyster larvae and post-settled spat abundances in pelagic and benthic habitats: two sites with collectors suspended inside shellfish farming structures (Bouzigues and Marseillan) and three with collectors suspended outside structures anchored on specially designed mooring systems (Listel, Meze_osfz and Balaruc) (Figure 1). Hydrological and planktonic data were monitored at the three sampling sites Bouzigues, Marseillan and Listel (Figure 1). 


\section{Abundance of young settlers and survival rate at metamorphosis}

As reported by Lagarde et al. (2017), young oyster abundances were estimated every two weeks at three different settler stages: pre-settled larvae (pediveliger), young postlarvae and newly settled juveniles (Arakawa 1990) from June to September in 2012, 2013 and 2014. An original method with a temporal overlap of collector deployment was used (Hughes et al. 2000, Arnold \& Steneck 2011, Lagarde et al. 2017). Pediveligers showed prodissoconch 2 (PII) shell sizes ranging from 180 to $300 \mu \mathrm{m}$, young postlarvae were strictly benthic and cemented with a dissoconch shell ranging from 300 to $1,000 \mu \mathrm{m}$ and newly settled juveniles (maximum four weeks old) measured from 1 to $8 \mathrm{~mm}$. To collect these settler stages, the sites were equipped with three replicated sets of two collectors each measuring $110 \mathrm{~cm}$ composed of 44 white plates (15 cm diameter; surface area $250 \mathrm{~cm} 2$, Figure $2 \mathrm{a}$ ).

The collectors were vertically submerged $2 \mathrm{~m}$ below the surface, suspended inside shellfish farming structures, or outside farming structures (see Figure 2(a) in Lagarde et al. (2017) for more details). The systems were designed to support two sets of collectors immersed for two or four weeks. Pediveliger and post larvae abundance was assessed on the 2-week collectors and oyster juvenile abundance was assessed on the 4-week collectors. After being sampled, the 4week collector was replaced with a new one, i.e. a replacement every two weeks throughout the summer. Each collector was sampled at three vertical levels: close to the top $\left(39^{\text {th }}\right.$ plate $)$, in the

middle $\left(22^{\text {th }}\right.$ plate) and at the bottom $\left(5^{\text {th }}\right.$ plate). Both faces of the plates (above and below) were examined under a binocular microscope to assess the mean abundance of pediveliger, post-larvae and newly settled juveniles, or macroscopically when possible. On each occasion, counting was evaluated on subunits, i.e. from one to four basic subunits $\left(15\right.$ to $\left.60 \mathrm{~cm}^{2}\right)$, replicated three times per face (Figure 2b). The abundance of each stage per plate was averaged from subunit counts 
and converted into total individual abundances per plate, and then expressed in relation to the sampling surface per $\mathrm{dm}^{2}$. Survival rates at metamorphosis corresponded to the ratio of the abundance of oyster juvenile survivors on the collectors immersed for four weeks divided by the pediveliger abundance on the collectors immersed for two weeks.

\section{Prodissoconch II size}

To assess prodissoconch II (PII) size, 10 postlarvae per plate were removed from three plates (at the top, middle and bottom of the collectors) and placed side by side on the microscope blade to obtain an optimal quantity of 30 measurements per site and per year for the main recruitment event in 2012, 2013 and 2014. Postlarvae were individually detached from their plate, placed and oriented on the plasticine flange of a holding blade (Martel et al. 2014) of an Olympus SZ61 binocular microscope. A digital microscope Keyence, VHX 2000 (200-300× magnification and set in high dynamic range mode with light shifts) was used to measure PII sizes. Based on a lateral view, PII heights were measured in accordance with a maximum dorsoventral dimension from the umbo to the most distant part of the clear demarcation formed by a growth line at the boundary layer between PII and dissoconch (Figure 3).

\section{Environmental measurements}

Hydrological and plankton samples were collected every Monday morning from June 1 to the September 30 in 2012, 2013 and 2014. Samples were collected at Listel and Mèze sites. Bouzigues and Marseillan sites were located less than $1 \mathrm{~km}$ from where environmental measurements are permanently monitored (REPHY - French Observation and Monitoring program for Phytoplankton and Hydrology 2017). For Bouzigues and Marseillan, hydrological and plankton samples associated with juvenile sampling sites were in biocoenosis, characterized 
by the same phytoplankton, zooplankton and benthic populations (Jarry et al. 1990, Jouffre et al. 1991, Guelorget et al. 1994).

Temperature and salinity were measured twice a week with $\mathrm{WTW}^{\circledR}$ probes positioned between 1 and $1.5 \mathrm{~m}$ below the surface. Oxygen concentrations were measured once a week at the bottom of the water column at the Bouzigues site..

The three sampling campaigns provided a total of 135 observations of plankton characteristics: 3 sampling sites x 15 weeks x 3 years. The Bouzigues, Meze_osfz and Marseillan sites were sampled in 2012 and the Bouzigues, Listel and Marseillan sites were sampled in 2013 and 2014. Each phytoplankton and protozooplankton sample was collected at each sampling site and date as subsamples of a 4 liter sample. Samples were collected weekly using a Standard Water Sampler acc. to Ruttner (Hydro-Bios Apparatebau $\mathrm{GmbH}$ ) without analytical replicates or sampling replicates.

For total chlorophyll $a$ [Total Chl. $a$ ] measurements, seawater samples $(200 \mathrm{~mL})$ were filtered (Bec et al. 2005, 2011) under vacuum $(<10 \mathrm{~cm} \mathrm{Hg})$ on Whatman GF/F membranes $(0.7 \mu \mathrm{m}$ porosity) and stored in glass tubes at $-20^{\circ} \mathrm{C}$. The filters were ground in $90 \%$ acetone and extracted for $24 \mathrm{~h}$ at $4{ }^{\circ} \mathrm{C}$ in the dark. Chlorophyll $a$ biomass was also determined after size fractioning (200 $\mathrm{ml}$ for picophytoplankton and $200 \mathrm{ml}$ for nanophytoplankton from the 41 sample) through Nuclepore membranes ( 3 and $20 \mu \mathrm{m}$, respectively) to determine the contribution of picophytoplankton (PICO, $<3 \mu \mathrm{m}$ ), nanophytoplankton (NANO, 3-20 $\mu \mathrm{m}$ ) and microphytoplankton (MICRO, > $20 \mu \mathrm{m}$ ) to total phytoplankton biomass. The pigment content ( $\mu \mathrm{gChla}$ $1^{-1}$ ) was measured using a spectrofluorometer (Perkin-Elmer LS50b)(Neveux \& Lantoine 1993). The abundances of picocyanobacteria (CYAN, $<1 \mu \mathrm{m}$ ), autotrophic picoeukaryotes (PEUK, $<3$ $\mu \mathrm{m}$ ) and nanophytoplankton (NANO TOT, 3-20 $\mu \mathrm{m}$ ) were measured on the basis of a sampled 
volume of $1 \mathrm{ml}$ with a Becton Dickinson FACSCalibur flow cytometer (Bec et al. 2011). Total picophytoplankton (PICO TOT) abundances were estimated as the sum of the CYAN and PEUK abundances. Among nanophytoplankton, Cryptophytes (CRYPTO) were distinguishable from other photosynthetic organisms (NANO) by their strong orange fluorescence associated with phycoerythrin pigment and their size. The abundances are expressed as $10^{6}$ cells $1^{-1}$.

To measure bacterial abundance, samples ( $1 \mathrm{ml}$ taken from the 41 sample) were fixed with prefiltered $(0.2 \mu \mathrm{m})$ buffered formaldehyde (final concentration $2 \%$ ) and stored in liquid nitrogen. The abundances were determined using the Becton Dickinson method with a FACSCalibur flow cytometer (Marie et al. 1997). The procedure was slightly modified as higher concentrations of fluorochrome (SYBR Green I) were used (Bouvy et al. 2016). One milliliter of fixed samples was incubated with SYBR Green I (Molecular Probes) at a final concentration of 1/375 for $15 \mathrm{~min}$ at $4{ }^{\circ} \mathrm{C}$ in the dark. Stained bacterial cells excited at $488 \mathrm{~nm}$ were determined according to their side-scattered light (SSC) and green fluorescence (FL1) and collected using a 530/30 nm filter. Fluorescent beads $(0.94 \mu \mathrm{m}$, Polysciences Inc.) were added to each sample. The taxonomic composition of protozooplankton was estimated (heterotrophic flagellates in a 30 $\mathrm{ml}$ sample and ciliates in a $100 \mathrm{ml}$ sample) and phytoplankton (in a10 $\mathrm{ml}$ sample) using the standard Utermohl method NF-EN-152014, 2006. For the phytoplankton, two main classes, "Diatoms" (aggregating 52 taxa) and "Dinoflagellates" (aggregating 38 taxa) were first used to explore the dataset. Taxonomic composition is expressed as the number of individuals per liter. The taxonomic composition of phytoplankton was not monitored in 2012 at the "Meze_osfz" sampling site. For analysis of heterotrophic flagellates (HF), the $30 \mathrm{ml}$ samples were preserved in an $8 \%$ formaldehyde solution and stored in a cold room at $4{ }^{\circ} \mathrm{C}$ in the dark until analysis. A 10 ml subsample was stained using 4',6-diamidino-2-phenylindole (DAPI) at a final concentration 
of $2.5 \mu \mathrm{g} \mathrm{ml}^{-1}$. The HF counts were performed using an epifluorescence microscope (Olympus AX70) with UV illumination (Sherr et al. 1993). For the determination of naked ciliates and tintinnids, $100 \mathrm{ml}$ samples were preserved in 2\% Lugol's iodine solution and kept in a cold room at $4{ }^{\circ} \mathrm{C}$ in the dark until analysis. Naked ciliates and tintinnids were identified, measured and counted with an inverted microscope (Olympus IX70) after a $100 \mathrm{ml}$ sample was left to settle in an Utermohl chamber for 24 h (Utermöhl 1931).

\section{Data analysis}

Data analyses and graphics were performed with R statistical software (R Core Team 2015).

Decimal logarithm transformations were used to tend towards linearity of response variables and to linearize the relationship with explanatory variables (Table 1). The environmental data from our three annual hydrobiological and plankton survey were averaged over a 14 day period before the retrieval of the collector during the main recruitment event.

The main recruitment events were identified each year by considering the highest oyster juvenile abundances observed at the different sampling sites. A non-parametric one way ANOVA (Kruskall test, 'pgirmess' package) was performed using data pooled for each date and associated with a multiple comparison test of Siegel and Castellan (Siegel \& Castellan 1988) to target the best sampling period for oyster recruitment at each sampling site each year. Oyster juvenile abundance was graphically described using comparison of means with standard error intervals.

A two-way cross Permanova (Permanova-Primer-E7.0.12 Permanova Plus; Primer-E Ltd, Plymouth, UK) was performed to compare PII size measured during the main oyster recruitment events among sampling sites (5 fixed levels: Marseillan, Listel, Meze_osfz, Bouzigues or Balaruc), year (3 fixed levels: 2012, 2013 and 2014) and their interaction (Site x Year). 
Resemblance matrixes were calculated on Bray-Curtis distances. Permanova was used rather than ANOVA because of non-orthogonality of our larval settler databases. This approach using similarities, like ANOVA, is more accurate than non-parametric analysis, because it uses the permutation method (9999 permutations). Homoscedasticity was verified by using the Permdisp test (Anderson et al. 2008).

A graphical representation of PII measurements and environmental variables was made with a principal component analysis (PCA) with the factor 'year and sampling site' (Lê et al. 2008). This PCA was used to explore and illustrate the heterogeneity of the three sampling sites according to the year and interactions between the PII sizes and their environment. The means of PII sizes were calculated using individuals from the collector replicates ( 1 collector is represented by 3 replicates of plates, each replicate is intended to optimally represent about 30 PII measurements). Each average PII size was compared with the averages of the environmental data acquired over the two weeks prior to the retrieval of the collector at the site. The broken stick model and Kaiser criterion were used to compare the eigenvalues and performed to interpret axes whose eigenvalues were higher than mean of all eigenvalues (Borcard et al. 2011, Oksanen et al. 2015). Linear models were used to fit regression and single stratum analysis of variance was performed following assumptions of random sampling, homoscedasticity (tested and confirmed with the Fligner-Killeen test) and normality (verified with Shapiro-Wilk tests), respectively to test the influence of year, temperature and survival at metamorphosis on the means of PII sizes. 


\section{RESULTS}

\section{Oyster spat abundance and survival after metamorphosis}

In 2012, two significant recruitment events were characterized (Figure 4). The first harvest date (August 13) was characterized by a juvenile abundance of $45 \pm 4$ ind. $\mathrm{dm}^{-2}$ at Listel and of $8 \pm 1$ ind. $\mathrm{dm}^{-2}$ at Bouzigues. The second significant recruitment event (September 25) was characterized by $14 \pm 2$ ind. $\mathrm{dm}^{-2}$ at Bouzigues, $12 \pm 2$ ind. $\mathrm{dm}^{-2}$ at Balaruc and $7 \pm 1$ ind. $\mathrm{dm}^{-2}$ at Listel. In 2013, the highest oyster juvenile abundances were recorded on August 13 and August 28 (Figure 4) highlighting excellent recruitment at the Meze_osfz sampling site with a density of $68 \pm 17$ ind. $\mathrm{dm}^{-2}$ and $92 \pm 17$ ind. $\mathrm{dm}^{-2}$. On August 28, the Listel site had an average juvenile oyster abundance of $32 \pm 5$ ind. $\mathrm{dm}^{-2}$ harvested, and a high juvenile abundance was also recorded at Meze_osfz on October 9, $2013\left(172 \pm 19\right.$ ind. $\left.\mathrm{dm}^{-2}\right)$. The 2014 profile revealed that the recruitment period lasted two months (Figure 4) with four consecutive recruitment events (August 13 and 27, and September 10 and 24). The Meze_osfz site showed remarkable juvenile abundances (75 \pm 6 ind. $\mathrm{dm}^{-2}, 260 \pm 27$ ind. $\mathrm{dm}^{-2}, 73 \pm 18$ ind. $\mathrm{dm}^{-2}, 30 \pm 6$ ind. $\mathrm{dm}^{-2}$ ) during these four consecutive events. The Listel site showed the same range of juvenile abundance as in 2012 and 2013 with $24 \pm 6$ ind. $\mathrm{dm}^{-2}$ on August 27 and $39 \pm 11$ ind. $\mathrm{dm}^{-2}$ on September 10. In 2014, it should be noted that experimental stations in the shellfish aquaculture zones (Bouzigues, Meze_osfz and Marseillan) had, on average, extremely low recruitment levels of between 0 and

2 ind. $\mathrm{dm}^{-2}$. Taken together, these results showed that the main oyster recruitment events occurred on August 13 in 2012, August 28 in 2013 and August 27 in 2014 (Figure 4).

\section{Prodissoconch II size}

PII size was determined during the main oyster recruitment event each year, $\underline{\text { i.e. }}$ on August 13, 2012, August 28, 2013 and August 27, 2014 (Figure 4). Permanova revealed a significant year 
and site interaction effect $\left(\mathrm{df}^{\text {yearxsite }}=7, \mathrm{df}^{\text {total }}=404\right.$, Pseudo-F $\left.=3.99, \mathrm{p}<0.001\right)$. In 2012, the pairwise Permanova showed significant differences in PII size depending on the site, with larger PII size (mean \pm se) at the Marseillan site $(\mathrm{p}<0.03 ; 247.0 \pm 5.2 \mu \mathrm{m}, \mathrm{n}=12)$ and smaller PII size at Balaruc ( $\mathrm{p}<0.02 ; 213.7 \pm 4.1 \mu \mathrm{m}, \mathrm{n}=31)$. In 2013, four size categories were observed (Figure 5), the largest PII size at Marseillan ( $\mathrm{p}<0.003 ; 270.7 \mu \mathrm{m} \pm 3.3 \mu \mathrm{m}, \mathrm{n}=35)$ and the smallest at Meze_osfz $(\mathrm{p}<0.01 ; 222.1 \pm 3.4 \mu \mathrm{m}, \mathrm{n}=35)$. In 2014, the PII size was categorized in two groups with larger sizes $(\mathrm{p}<0.001)$ at the Marseillan site $(273.2 \pm 5.2 \mu \mathrm{m}, \mathrm{n}=11)$, Bouzigues $(265.9 \pm$ $3.8 \mu \mathrm{m}, \mathrm{n}=24)$ and Balaruc $(275.0 \pm 2.6 \mu \mathrm{m}, \mathrm{n}=15)$ and smaller $(\mathrm{p}<0.001)$ in Listel $(254.8 \pm 4.5$ $\mu \mathrm{m}, \mathrm{n}=30)$ and Meze_osfz $(243.8 \pm 4.3 \mu \mathrm{m}, \mathrm{n}=35)$.

\section{Relations between PII size, hydrology and plankton data}

A principal component analysis was conducted on the hydrological measurements, plankton data and PII sizes to explore their relationship and to characterize structured ecological gradients and spatial patterns (Figure 6). Applying the "broken stick" model and Kaiser criterion, four axes were mainly explanatory but only the first three axes are shown because they each individually represent more than $10 \%$ of the total inertia (Figure 6a). On the Dim1/Dim2 plot (Figure 6b), the first axis opposed autotrophic organism (bottom right; biomass and abundance of nanophytoplankton and biomass of total chlorophyll $a$ with hetero/mixotrophic organisms (top left; $\mathrm{fh}^{\mathrm{A}}$, tintinnids $^{\mathrm{A}}$, ciliates $^{\mathrm{A}}$ and crypto $^{\mathrm{A}}$ ). The second axis was mainly driven by abundances of picoplanktonic organisms such as ciliates ${ }^{\mathrm{A}}$, peuk $^{\mathrm{A}}$ and crypto $^{\mathrm{A}}$. The first two axes accounted for $64.0 \%$ of variance. Although weakly represented on the factorial plane of axes 1 and 2, the PII size appeared to be positively correlated with hetero/mixotrophic organisms such as Crypto ${ }^{\mathrm{A}}$ and Ciliates $^{\mathrm{A}}$ and anti-correlated with the variables representing autotrophic organisms (biomass and abundance of nanophytoplankton and total chlorophyll $a$ biomass. The low representation of the 
PII size variable on these first two axes reveals the marked influence of ecological heterogeneity and gradients in the ecosystem in response to the observed biological effect. The Dim1/Dim3 plot (Figure 6c) shows that in planes 1 and 3, the right part of plot showed high and positive contributions of autotrophic organisms (diatoms ${ }^{\mathrm{A}}$, nano ${ }^{\mathrm{A}}$, nano ${ }^{\mathrm{B}}$, total chlorophyll $a^{\mathrm{B}}$ and cyan ${ }^{\mathrm{A}}$ ) and the left part showed negative contributions by $\mathrm{fh}^{\mathrm{A}}$, crypto $^{\mathrm{A}}$ and ciliates ${ }^{\mathrm{A}}$. The Dim2-Dim3 plot (Figure 6d) shows the correlations between the variables on axes 2 and 3 with axis 3 (12.6\%) opposing PII size and Tintinnids ${ }^{\mathrm{A}}, \mathrm{fh}^{\mathrm{A}}$, temperature and bacteria ${ }^{\mathrm{A}}$. The distribution of sampling sites in factorial planes 1-2 indicates that the sites expressed their heterogeneity differently between years with respect to the autotrophic or hetero/mixotrophic regime (Figure 6e, f, g). The sites Marseillan 2012, Marseillan 2014, and Bouzigues 2014 had the biggest PII, the highest heterotrophic abundances and the lowest phytoplankton biomass and abundance. The Listel site had the smallest PII size. Overall, the right to left progression from autotrophic to heterotrophic is_clear on the first two axes whereas the temperature has a structuring effect and is related to the sizes of PII on the first two axes of this ACP.

Annual averages (mean \pm se) of size at metamorphosis increased significantly (Anova, $\mathrm{F}$ value $=48.5, \mathrm{p}<0.0001$, Figure 7a) from $2012(226.7 \pm 23.3 \mu \mathrm{m}, \mathrm{n}=113)$ to $2013(248.0 \pm$ $25.99 \mu \mathrm{m}, \mathrm{n}=177)$ and $2014(258.2 \pm 24.50 \mu \mathrm{m}, \mathrm{n}=115)$.

Water temperature (mean \pm se) during the main oyster recruitment events was on average $25.7 \pm$ $0.1{ }^{\circ} \mathrm{C}$ in $2012,24.8 \pm 0.1{ }^{\circ} \mathrm{C}$ in $2013,23.3 \pm 0.1{ }^{\circ} \mathrm{C}$ in 2014 (Figure 7) with a significant anticorrelation with PII size (Spearman's correlation coefficient $=-0.74$ and $\mathrm{p}<0.001)$ (Figure 7b). Figure 8 shows six trophic parameters significantly correlated with PII size $(\mathrm{p}<5 \%)$; Cryptophyte abundances were positively correlated (Corr. Coef. $=0.69$ and $\mathrm{p}<0.001$ ) and anticorrelated with total chlorophyll $-a$ biomass (Corr. Coef. $=-0.51$ and $\mathrm{p}<0.01$ ), micro- 
phytoplankton biomass (Corr. Coef. $=-0.77$ and $\mathrm{p}<0.001$ ), nanophytoplankton biomass (Corr. Coef. $=-0.57$ and $\mathrm{p}<0.05$ ), picocyanobacteria (corr. Coef. $=-0.62$ and $\mathrm{p}<0.05$ ) and tintinnid abundances (Corr. Coef. $=-0.41$ and $\mathrm{p}<0.01)$.

\section{Relation between PII size and survival after metamorphosis}

Figure 9 shows a negative linear relation between PII sizes and survival after metamorphosis (cor. Coef $=-40.8 \%$, df. $=379, \mathrm{p}<0.0001)$. The significant negative slope $(\mathrm{b}=-40.9, \mathrm{p}<$ 0.0001) shows that juvenile survival decreased with an increase in PII size (Table 2). The value of $254.8 \mu \mathrm{m}(\mathrm{p}<0.0001)$ at the intercept for PII size indicates low survival compared to 213.9 $\mu \mathrm{m}$ for high juvenile survival. The proportion of variance explained by the regression is relatively low (multiple R-squared $=0.167$ ) compared to the total dispersion because of the great variability of the PII sizes measured.

\section{DISCUSSION}

In a new context of oligotrophication, our overall objective was to explore variability of recruitment of Crassostrea gigas, the most highly exploited bivalve species in the world (FAO 2012). This is the first time variability of prodissoconch II size has been assessed during the main oyster recruitment events in C. gigas in a semi-enclosed nanotidal ecosystem, Thau lagoon in southern France. Likewise, the hypothesis that, in C. gigas, larger size at metamorphosis is linked to lower juvenile survival rates was confirmed. The retention of competent larvae in the water column was mainly related to temperature and environmental/trophic conditions. Contrariwise, rapid settlement and metamorphosis at a smaller size increased the survival probability of Pacific oyster juveniles and had a positive impact on recruitment success. The recruitment variability of benthic invertebrates has already been studied to ensure the sustainability of the established populations (Pechenik 2006, St-Onge et al. 2015, Barbier et al. 
2017). In our case, monitoring in 2012, 2013 and 2014 revealed spatial and temporal patterns that had an environmental influence on different stages, i.e. spawning, settlement and metamorphosis (Lagarde et al. 2017, Ubertini et al. 2017). This shows that the intrinsic ecological functioning of the lagoon combined with heterotrophic/mixotrophic vs. autotrophic regimes (Leruste et al. 2016) can influence gametogenesis, spawning behavior, settlement of larvae, and hence recruitment success. As already described for lakes, these changes in functioning affect the trophic chain through a cascade of interactions extending from bacteria to fish (Jeppesen et al. 1998, 2005, Ozkan et al. 2016). The concept of a time window for recruitment, as described by Pineda et al. (2006), is fully applicable to the recruitment abundances in our study context. The ecological specificities of Thau lagoon are expressed in the heterogeneous oyster recruitment within the narrow recruitment windows defined by specific spatial and temporal patterns (Lagarde et al. 2017). The temporal component of Pacific oyster recruitment in the lagoon according to three determinants: (i) The recruitment determinant is the temperature of the ecosystem that results in different ecological functioning (hypoxic / normoxic, autotrophic / heterotrophic); (ii) the determinant of pediveligers abundance is the abundance of diatoms Chaetoceros spp; (iii) the determinant of metamorphosis survival is the abundance of nanophytoplankton. It is known that Thau lagoon is spatially heterogeneous due to its topogeography, currents, confinement and its intensive exploitation for shellfish farming. The effects of shellfish farming on the ecosystem are well known, particularly significant depletions of biomass and abundance of plankton in shellfish growing areas due to bivalve filtration (Deslous-Paoli et al. 1993, Lam-Hoai et al. 1997, Mazouni, Deslous-Paoli, et al. 1998). Lagarde et al. (2017) showed that plankton depletion, including Chaetoceros spp and nanophytoplankton, are not favorable for a larval cycle up to recruitment, particularly in periods of top-down trophic 
control of shellfish areas by filter feeders during recruitment windows.

The larval stage and particularly the steps of metamorphosis may be delayed depending on environmental functioning (Lutz \& Jablonski 1978, Pechenik 1990, 1999, 2006). Martel et al. (2014) highlighted the relation between a longer delay before metamorphosis, an increase in the PII size of the blue mussel Mytilus edulis and a decrease in settlement and recruitment success. In the present study, in situ spatial and temporal patterns of prodissoconch II sizes were identified for the first time in C. gigas based on environmental cues. Prodissoconch II heights were measured during the best recruitment windows each year as representative of the functioning scenarios of the entire Thau basin exploited for shellfish farming. The variation in size was on average $20 \%$ per sampling site with individual maxima of up to $40 \%$, i.e., from 180 to $296 \mu \mathrm{m}$. Our results suggest that the yearly temporal pattern is mainly driven by temperature, while the higher spatial variability of PII size is related to the quantity and quality of available food (autotrophic vs. heterotrophic regime) for larvae and juveniles (Lagarde et al. 2017, Ubertini et al. 2017). Further study is needed on the impacts of delayed metamorphosis on the duration of larval pelagic stage, changes in PII sizes in terms of physiological states or indicators such as energy reserves, total lipids and essential fatty acids.

Temperature controls activities that affect the kinetics of the biological and ecological processes (Frontier \& Pichod-Viale 1998). It is known that temperature determines the patterns of distribution of organisms as a function of gradients and discontinuities (Hochachka et al. 2002). At an individual scale, the growth rates of poikilotherm organisms are governed by temperature. Temperature has a direct effect on the physiology of oyster larvae by enabling high metabolism rates (Rico-Villa et al. 2010) thereby accelerating development, but temperature may not affect total metabolic demand (Hoegh-Guldberg et al. 1991). In the present study, the annual means of 
PII size were anti-correlated with water temperature (2012: $25.7^{\circ} \mathrm{C}, 2013: 24.8^{\circ} \mathrm{C}, 2014: 23.3$

${ }^{\circ} \mathrm{C}$ ), which contradicts the physiological rules and disagrees with the results obtained by Arakawa (1990), who studied the eutrophicated Hiroshima Bay in the 1990s. However, this negative correlation between seawater temperature and PII size has already been reported in Mya arenaria (Lutz \& Jablonski 1978), Mytilus edulis (Bayne 1965) and Crassostrea gigas (FloresVergara et al. 2004). This relationship could be due to the longer time available for feeding and growth at lower temperatures. At high temperatures, the transition between feeding stages, such as velum resorption, is shortened, and could result in smaller PII sizes (Lutz and Jablonski, 1978).

The temperature of the sea water has known effects on the activation of spat oyster pathogens such as the Ostreid herpes virus OsHV-1 and bacteria of the group Vibrio splendidus (Pernet et al. 2012, Petton, Boudry, et al. 2015, Petton, Bruto, et al. 2015). OsHV-1 mortality in France started in early May and lasted until late September, with an interruption in July and August when seawater temperatures increased from $16{ }^{\circ} \mathrm{C}$ to more than $23{ }^{\circ} \mathrm{C}$ (Pernet et al. 2014). In our study context, reproduction and recruitment processes were mainly studied in a temperature window ranging from $23{ }^{\circ} \mathrm{C}$ to $27^{\circ} \mathrm{C}$. We thus presume that pathogen agent OsHV-1 was not active during our recruitment window.

Temperatures drastically affect the whole ecological functioning of the Mediterranean lagoon in summer (Chapelle, Lazure, et al. 2000, Chapelle, Ménesguen, et al. 2000). In the case of high summer temperatures, diatoms, cryptophytes and chlorophyta are known to represent phytoplankton communities in this mesotrophic Mediterranean lagoon (Collos et al. 2009, Bec et al. 2011, Leruste et al. 2016). Moreover, a spatial gradient in ecological functioning was revealed with smaller PII sizes in the middle of the ecosystem (Listel and Meze_osfz) and larger sizes at 
the eastern (Marseillan) and western (Balaruc) ends. Analysis of environmental variables showed that the smaller PII sizes associated with better survival were driven by higher biomass of autotrophic organisms such as picocyanobacteria, nano and micro-phytoplankton and total chlorophyll $a$ biomass. In contrast, larger PII sizes with lower survival rates were associated with lower autotrophic biomass. The significant negative correlation between PII size and nanophytoplankton and micro-phytoplankton biomass highlights the importance of the planktotrophic relationship during settlement and metamorphosis (Toupoint et al. 2012). Our results are in agreement with those of Toupoint et al. (2012), who showed in the blue mussel that high cyanobacteria, pico- and nano-eukaryote biomasses were correlated with better recruitment. Considering a context of heterogeneity caused, on the one hand, by the effects of depletion due to shellfish farming areas and on the other hand, by geographical gradients, we hypothesize that pico-organisms (cyanobacteria eukaryotes), nano- and micro-phytoplankton biomasses act as a trigger for trophic settlement, as already demonstrated in mussels (Toupoint et al. 2012, Martel et al. 2014), and given their impact on PII size, probably also trigger metamorphosis.

Our results show that high cryptophyte abundances correspond to large PII sizes. Cryptophytes are mixotrophic nano-flagellates that play a role in the remineralization of organic matter and in predation on picoplankton such as the Synechococcus sp. picocyanobacteria (Yoo et al. 2017) and bacteria (Klaveness 1989, Pastoureaud et al. 2003). The appearance of picocyanobacteria (mostly Synechococcus sp.) has been reported to be related to a reduction in nutrient loading and to an increase in water temperature (Collos et al. 2009). Cryptophyte abundance and biomass respond rapidly to both nutrient loads and picocyanobacteria prey abundance due to their high growth rate (Yoo et al. 2017). These mixotrophic features (Cloern \& Dufford 2005) make cryptophytes revealers of a transitional state during oligotrophication. What is more, thanks to 
their high nutritional values, digestibility and nanophytoplankton size, cryptophytes are considered as good prey for filter feeders like adults oysters (Klaveness 1989, Pastoureaud et al. 2003). However, cryptophytes have ejectile organelles named trichocysts/ejectosoms (Klaveness 1989) that may play a defensive role against predation by protozoa (Yamagishi et al. 2012). It has also been reported that, in the case of Raphidophyceae in lake ecosystems, trichocysts may also act as repellents to grazers (Lebret et al. 2012). Here, we hypothesize that the anatomy of cryptophytes with trichocysts/ejectosoms would be inappropriate for larval development and would thus be metamorphosis inhibitors/delayers. Of course, this hypothesis needs to be tested in experimental studies. Tintinnids are heterotroph organisms, predators of phytoplankton, specifically of nano-phytoplankton, including cryptophytes, COD and bacteria (Dolan 2000, Sitran et al. 2009). Tintinnid abundance probably reflects picocyanobacteria populations and cryptophyte dynamics and acts as a booster of settlement or metamorphosis or perhaps just as a neutral trophic competitor of oyster larvae, revealing mixo/heterotrophic traits of oligotrophication process. These results fill some of the many gaps in our knowledge of the interactions between cryptophytes, ciliates and oyster larvae.

Bacteria have been shown to facilitate the settlement of many invertebrate larvae, including oysters (Fitt et al. 1989, 1990, Coon et al. 1990). In the present study, we show that high picocyanobacteria abundance corresponds to small PII size. We hypothesize that picocyanobacteria abundance boosts settlement or metamorphosis in the presence of an efficient trophic chain.

The functional approach (heterotrophic vs. autotrophic) has been used to understand how environmental changes or gradients drive phytoplankton community structure (Litchman et al. 2010, Leruste et al. 2016). Some morphological and physiological traits, in particular cell size, 
maximum growth rate and trophic regime reflect how phytoplankton adapt to nutrient availability (Litchman et al. 2007, 2010). During oligotrophication, the reduction in nutrient inputs could thus favor small cells, which compete more effectively for nutrient uptake and have high growth rates (Chisholm 1992, Kamenir \& Morabito 2009, Litchman et al. 2010), and mixotrophic species, which have some advantages over strictly autotrophic cells (Anneville \& Pelletier 2000). In our case, an ecosystem with heterotrophic functioning indeed resulted in sizes at metamorphosis ranging from 250 to $300 \mu \mathrm{m}$, while autotrophic functioning resulted in sizes ranging from 200 to $250 \mu \mathrm{m}$. This ecological heterogeneity expresses a specificity of Thau lagoon with regard to PII size, i.e., an west-east gradient that tended to be linear in 2012 (with the largest sizes in the west and the smallest in the east) and another gradient as a reverse parabolic curve in 2013 and 2014 that recalls the optimal production curves of Shelford's law of tolerance (Begon et al. 2007). The central zone of the lagoon represented by the "Meze_osfz" site appears to be the zone of ecological preference (with small PII size, high survival and high recruitment rates) and, at both west and east ends of the lagoon, tolerance limits of the species with high PII sizes, lower survival and recruitment rates.

Concerning the impact of a shellfish exploitation zone, the influence of filter feeders (oysters and their epibiota) on the spatial distribution of particulates and dissolved compounds determines the biogeochemical processes both in the water column (Mazouni, Gaertner, et al. 1998, Chapelle, Lazure, et al. 2000, Chapelle, Ménesguen, et al. 2000) and in the sediment (Mazouni et al. 1996, Gilbert et al. 1997). The biocoenosis caused by shellfish farming results in specific ecological functioning and in a tenfold reduction in nanophytoplankton, and micro-phytoplankton biomass (Tournier \& Pichot 1987, Jarry et al. 1990, Souchu et al. 2001) as well as in microzooplankton included tintinnids, rotifers, anthozoan larvae and crustacean and mollusk larvae compared to 
values measured in the middle of the lagoon (Lam-Hoai et al. 1997). This ecological heterogeneity, as exemplified by the Thau basin, should affect some marine invertebrate larvae (Borsa \& Millet 1992) and affect oyster recruitment at biocoenosis scale.

Our results showed that the best metamorphosis survival rate was associated with small PII size. Our results are in agreement with those of Martel et al. (2014) on Mytilus edulis and support the hypothesis that inter-annual variations in the adult population of most benthic invertebrates are not only related to variability in larval supply, but even more to post-settlement processes (Gosselin \& Qian 1997, Hunt \& Scheibling 1998, Fuchs et al. 2013).

In Hiroshima bay, the first industrial spatfall basin of C. gigas in Japan, the ratio of the nano- and pico-phytoplankton (>10-20 micro m) to total chlo $a$ in 2010 clearly decreased when the lack of natural oyster recruitment became serious (Hori, com. pers.). In comparison with the 1990s, when recruitment was successful, the ratio of nano- and pico-phytoplankton to total chlorophyll $a$ was more than $90 \%$ from May to September (Sik Lee et al. 1996) whereas in 2017, the ratio was less than 30-60\% (Matsubara, unpublished data). In France, temperature related nanophytoplankton have been shown to have a significant influence on the success of recruitment in both the Arcachon basin and Thau lagoon (Auby \& Maurer 2004, Lagarde et al. 2017). These results in France and Japan reinforce the hypothesis that the origin of the variability in the success of larval development, metamorphosis and recruitment in natural spatfall basins is mainly driven by a combination of temperature and the quality and quantity of phytoplankton. Other studies conducted in Atlantic coastal ecosystems also support this hypothesis (Pouvreau 2015). 


\section{CONCLUSION}

In the presence of ecological heterogeneity, plasticity responses in larval traits can affect size at metamorphosis, juvenile development, and recruitment survival. Ecological structuring offers different kinds of pelagic and benthic habitats that correspond to recruitment windows (Pineda et al. 2006, Buckley et al. 2010) some of which may be optimal (Cury \& Roy 1989, Pineda et al. 2006, Lagarde et al. 2017). Pechenik (1990) emphasized the absolute need for field studies to assess variability of PII size, delays in metamorphosis and their impact on juvenile survival and development. Our work helps characterize interactions between planktonic larvae and trophic and environmental conditions, including the impact of filterfeeders on the recruitment of $C$. gigas. This study highlights for the first time the existence of variability in prodissoconch II size in $C$. gigas during major oyster recruitment events in the French Mediterranean Thau lagoon in 2012, 2013 and 2014. PII size varied with the temperature and with trophic conditions and was smaller under high water temperature conditions combined with high nano and micro-phytoplankton biomass, and with tintinnid and picocyanobacterial abundances. Inversely, when cryptophytes were more abundant and water temperatures were lower, the larvae that settled and metamorphosed were bigger. We also demonstrated that the survival rate of smaller prodissoconch II shells was higher while the larger PII sizes had lower survival rates. Under oligotrophication, we hypothesize that in a favorable autotrophic context, it is better for larvae survival to metamorphose early and to be smaller whereas in unfavorable heterotrophic/mixotrophic conditions, the larvae were bigger with potential metamorphosis delays. Links with trophic conditions need to be confirmed by studying the relation between the energetic values of nano-seston and postlarvae during major recruitment events. Further laboratory experiments are recommended to test the link between 
size at metamorphosis, energetic reserves of larvae and the delay in metamorphosis in different trophic conditions. The negative influence of cryptophytes on metamorphosis also needs to be confirmed in lab experiments. These innovative results lead us to hypothesize that the shift from an autotrophic to a heterotrophic system could increase the variability of $C$. gigas recruitment and possibly jeopardize the sustainability of shellfish farming in coastal ecosystems undergoing oligotrophication.

\section{ACKNOWLEDGEMENTS}

The authors are grateful to the funders of the "PRONAMED 2" project: France-Agrimer, Conseil Régional d'Occitanie/Languedoc-Roussillon, Conseil départemental de l'Hérault, Comité Régional de la Conchyliculture en Méditerranée, Cepralmar and Ifremer. FL and RT thank the RECHAGLO international research group, co-funded by Ifremer and MPO, for encouragement, support, and exchanges with Canada. FL, MHo and MHa thank JSPS and Campus France/Ministry of Foreign Affairs for funding the scientific exchange needed for this study. FL is grateful to Martin Ubertini and Annie Fiandrino for their contribution to spatial experimental design. This work also benefited from the database of the VELYGER network (larvae abundances of oysters, http://doi.org/10.17882/41888). Our special thanks to Adeline Perignon, Erika Gervasoni, Patrik Le Gall, Slem Meddah, Solen Soriano, Axel Leurion, Nathalie Gauthier and Alana Correia-Martins for their assistance, their involvement and commitment during both field and laboratory work.

\section{LITERATURE CITED}

Alvarez-Cobelas M, Rojo C (2000) Ecological goal functions and plankton communities in lakes. J Plankton Res 22:729-748

Anderson MJ, Gorley RN, Clarke KR (2008) PERMANOVA+ for PRIMER: Guide to Software 
and Statistical Methods.

Anneville O, Pelletier JP (2000) Recovery of Lake Geneva from eutrophication: quantitative response of phytoplankton. Fundam Appl Limnol 148:607-624

Arakawa KY (1990) Natural Spat Collecting in the Pacific Oyster Crassostrea gigas (Thunberg). Mar Behav Physiol 17:95-128

Arnold SN, Steneck RS (2011) Settling into an increasingly hostile world: The rapidly closing "recruitment window" for corals. PLoS One 6

Auby I, Maurer D (2004) Study of the reproduction of oysters in the Arcachon Basin. Ifremer Report, R.INT.DEL/AR 04-05. 203p.

Baker SM, Mann R (1994) Description of metamorphic phases in the oyster Crassostrea virginica and effects of hypoxia on metamorphosis. Mar Ecol Prog Ser 104:91-99

Baker P, Mann R (1998) Response of settling oyster larvae, Crassostrea virginica, to specific portions of the visible light spectrum. J Shellfish Res 17:1081-1083

Barbier P, Meziane T, Forêt M, Tremblay R, Robert R, Olivier F (2017) Nursery function of coastal temperate benthic habitats: New insight from the bivalve recruitment perspective. J Sea Res 121:11-23

Bayne BL (1965) Growth and the delay of metamorphosis of the larvae of Mytilus edulis (L.). Ophelia 2:1-47

Bayne BL (1976) Marine mussels : their ecology and physiology. Cambridge University Press, Cambridge

Bayne BL (2017) Biology of Oysters, Developments in Aquaculture and Fisheries Science. (Elsevier, Ed.), Academic P. Volume 41

Bec B, Collos Y, Souchu P, Vaquer A, Lautier J, Fiandrino A, Benau L, Orsoni V, Laugier T 
(2011) Distribution of picophytoplankton and nanophytoplankton along an anthropogenic eutrophication gradient in French Mediterranean coastal lagoons. Aquat Microb Ecol 63:29-45

Bec B, Husseini-Ratrema J, Collos Y, Souchu P, Vaquer A (2005) Phytoplankton seasonal dynamics in a Mediterranean coastal lagoon: Emphasis on the picoeukaryote community. J Plankton Res 27:881-894

Begon M, Colin RT, Harper JL (2007) Ecology - From Individuals to Ecosystems, 4th ed., Blackwell Publishing, Oxford, 738 pages.

Bhaud M (2000) Two contradictory elements determine invertebrate recruitment: Dispersion of larvae and spatial restrictions on adults. Oceanol Acta 23:409-422

Bishop CD, Erezyilmaz DF, Flatt T, Georgiou CD, Hadfield MG, Heyland A, Hodin J, Jacobs MW, Maslakova SA, Pires A, Reitzel AM, Santagata S, Tanaka K, Youson JH (2006) What is metamorphosis? Integr Comp Biol 46:655-661

Borcard D, Gillet F, Legendre P (2011) Numerical Ecology with R., Springer.

Borsa P, Millet B (1992) Recruitment of the clam Ruditapes decussatus in the lagoon of Thau, Mediterranean. Estuar Coast Shelf Sci 35:289-300

Bouvy M, Got P, Domaizon I, Pagano M, Leboulanger C, Bouvier C, Carre C, Roques C, Dupuy C (2016) Plankton communities in the five Iles Eparses (Western Indian Ocean) considered to be pristine ecosystems. Acta oecologica- Int J Ecol 72:9-20

Buckley LJ, Lough RG, Mountain D (2010) Seasonal trends in mortality and growth of cod and haddock larvae result in an optimal window for survival. Mar Ecol Prog Ser 405:57-69

Bullock JM, Aronson J, Newton AC, Pywell RF, Rey-Benayas JM (2011) Restoration of ecosystem services and biodiversity: conflicts and opportunities. Trends Ecol Evol 26:541- 
Cannuel R, Beninger PG (2006) Gill development, functional and evolutionary implications in the Pacific oyster Crassostrea gigas (Bivalvia: Ostreidae). Mar Biol 149:547-563

Chapelle A, Lazure P, Souchu P (2000) Modelling anoxia in the Thau lagoon (France). Oceanol Acta 24:S87-S97

Chapelle A, Ménesguen A, Deslous-Paoli LM, Souchu P, Mazouni N, Vaquer A, Millet B (2000) Modelling nitrogen, primary production and oxygen in a Mediterranean lagoon. Impact of oysters farming and inputs fom the watershed. Ecol Modell 127:161-181

Chisholm SW (1992) Phytoplankton Size. Primary Productivity and Biogeochemical Cycles in the Sea. In: Springer (ed)p 213-237.

Cloern JE (2001) Our evolving conceptual model of the coastal eutrophication problem. Mar Ecol Prog Ser 210:223-253

Cloern JE, Dufford R (2005) Phytoplankton community ecology: Principles applied in San Francisco Bay. Mar Ecol Prog Ser 285:11-28

Collos Y, Bec B, Jauzein C, Abadie E, Laugier T, Lautier J, Pastoureaud A, Souchu P, Vaquer A (2009) Oligotrophication and emergence of picocyanobacteria and a toxic dinoflagellate in Thau lagoon, southern France. J Sea Res 61:68-75

Coon SL, Fitt WK, Bonar DB (1990) Competence and delay of metamorphosis in the Pacific oyster Crassostrea gigas. Mar Biol 106:379-387

Cury P, Roy C (1989) Optimal environnemental window and pelagic fish recruitment success in up welling areas. Can J Fish Aquat Sci 46:670-680

Dame RF (2012) Ecosystem Health, Restoration and Services. In: Press C (ed) Ecology of marine bivalves : an ecosystem approach, 2nd ed.p 235-257 
Deslous-Paoli JM, Mazouni N, Souchu P, Landrein S, Pichot P, Juge C (1993) Oyster Farming Impact on the Environment of a Mediterranean Lagoon (THAU)(Preliminary results of the OXYTHAU programme). In: Dame RF (ed) Bivalve Filter Feeders: in Estuarine and Coastal Ecosystem Processes. Springer Berlin Heidelberg, Berlin, Heidelberg, p 519-521

Dolan JR (2000) Tintinnid ciliate diversity in the Mediterranean Sea: longitudinal patterns related to water column structure in late spring - early summer. Aquat Microb Ecol 22:6978

Duarte CM, Conley DJ, Carstensen J, Sánchez-camacho M (2009) Return to Neverland: Shifting baselines affect eutrophication restoration targets. Estuaries and Coasts 32:29-36

FAO (2012) La situation mondiale des pêches et de l'aquaculture. Rome. 241p.

Fitt WK, Coon SL, Walch M, Weiner RM, Colwell RR, Bonar DB (1990) Settlement behavior and metamorphosis of oyster larvae (Crassostrea gigas) in response to bacterial supernatants. Mar Biol 106:389-394

Fitt WK, Labare MP, Fuqua WC, Walch M, Coon SL, Bonar DB, Colwell RR, Weiner RM (1989) Factors influencing bacterial production of inducers of settlement behavior of larvae of the oyster Crassostrea gigas. Microb Ecol 17:287-298

Flores-Vergara C, Cordero-Esquivel B, Cerón-Ortiz AN, Arredondo-Vega BO (2004) Combined effects of temperature and diet on growth and biochemical composition of the Pacific oyster Crassostrea gigas (Thunberg) spat. Aquac Res 35:1131-1140

Frontier S, Pichod-Viale D (1998) Ecosystèmes - structure, fonctionnement, évolution. (Masson, Ed.).

Fuchs HL, Hunter EJ, Schmitt EL, Guazzo RA (2013) Active downward propulsion by oyster larvae in turbulence. J Exp Biol 216:1458-1469 
Gilbert F, Souchu P, Bianchi M, Bonin P (1997) Influence of shellfish farming activities on nitrification, nitrate reduction to ammonium and denitrification at the water-sediment interface of the Thau lagoon, France. Mar Ecol Prog Ser 151:143-153

Gosselin LA, Qian PY (1997) Juvenile mortality in benthic marine invertebrates. Mar Ecol Prog Ser 146:265-282

Gowen RJ, Collos Y, Tett P, Scherer C, Bec B, Abadie E, Allen M, O’Brien T (2015) Response of diatom and dinoflagellate lifeforms to reduced phosphorus loading: A case study in the Thau lagoon, France. Estuar Coast Shelf Sci 162:45-52

Guelorget O, Perthuisot J-P, Lamy N, Lefebvre A (1994) Structure and organization of Thau lagoon in terms of benthic fauna (macrofauna-meiofauna). Relations with confinement. Ocean Acta 17:105-114

Hadfield MG, Carpizo-Ituarte EJ, Carmen K del, Nedved BT (2001) Metamorphic Competence, a Major Adaptive Convergence in Marine Invertebrate Larvae1. Am Zool 41:1123-1131

Hochachka PPW, Somero GN, Viña J (2002) Biochemical adaptation: Mechanism and process in physiological evolution. Biochem Mol Biol Educ 30:215-216

Hoegh-Guldberg O, Welborn JR, Manahan DT (1991) Metabolic requirements of Antarctic and temperate asteroid larvae. Antarct J US 26:163-165

Hughes TP, Baird AH, Dinsdale EA, Moltschaniwskyj NA, Pratchett MS, Tanner E, Willis BL (2000) Supply-side ecology works both ways: the link between benthic adults, fecundity, and larval recruits. Ecology 81:2241-2249

Hunt HL, Scheibling RE (1998) Spatial and temporal variability of patterns of colonization by mussels (Mytilus trossulus, M. edulis) on a wave-exposed rocky shore. Mar Ecol Prog Ser 167:155-169 
Jarry V, Fiala M, Frisoni GF, Jacques G, Neveux J, Panouse M (1990) The spatial distribution of phytoplankton in a Mediterranean lagoon (Etang de Thau). Oceanol Acta 13:503-512

Jenewein BT, Gosselin LA (2013) Ontogenetic shift in stress tolerance thresholds of Mytilus trossulus : Effects of desiccation and heat on juvenile mortality. Mar Ecol Prog Ser $481: 147-159$

Jeppesen E, Søndergaard M, Jensen JP, Havens KE, Anneville O, Carvalho L, Coveney MF, Deneke R, Dokulil MT, Foy B, Gerdeaux D, Hampton SE, Hilt S, Kangur K, Köhler J, Lammens EHHR, Lauridsen TL, Manca M, Miracle MR, Moss B, Nõges P, Persson G, Phillips G, Portielje R, Romo S, Schelske CL, Straile D, Tatrai I, Willén E, Winder M (2005) Lake responses to reduced nutrient loading - An analysis of contemporary long-term data from 35 case studies. Freshw Biol 50:1747-1771

Jeppesen E, Søndergaard M, Jensen JP, Mortensen E, Hansen A-M (1998) Cascading Trophic Interactions from Fish to Bacteria and Nutrients after Reduced Sewage Loading: An 18Year Study of a Shallow Hypertrophic Lake. Ecosystems 1:250-267

Jonge VN De, Elliott M (2001) Eutrophication. (K Steele, J., Thorpe, S., Turekian, Ed.), Academic P. London

Jouffre D, Lamhoai T, Millet B, Amanieu M (1991) Spatial structuring of zooplankton communities and hydrodynamic pattern in coastal lagoons. Oceanol acta 14:489-504 Kamenir Y, Morabito G (2009) Lago Maggiore oligotrophication as seen from the long-term evolution of its phytoplankton taxonomic size structure. J Limnol 68:146-161

Kennish MJ, Lutz PL, McEdward L (1995) Ecology of marine invertebrate larvae. (CRC Press., Ed.). Boca Raton, Florida

Klaveness D a G (1989) Biology and ecology of the Cryptophyceae : Status and challenges. Biol 
Oceanogr 6:257-270

Lagarde F, Roque E, Ubertini M, Mortreux S, Bernard I, Fiandrino A, Chiantella C, Bec B, Roques C, Bonnet D, Miron G, Richard M, Pouvreau S, Lett C, Marbec IUMR (2017) Recruitment of the Pacific oyster Crassostrea gigas in a shellfish-exploited Mediterranean lagoon : discovery, driving factors and a favorable environmental window. Mar Ecol Prog Ser 578:1-17

Lam-Hoai T, Rougier C, Lasserre G (1997) Tintinnids and rotifers in a northern Mediterranean coastal lagoon. Structural diversity and function through biomass estimations. Mar Ecol Prog Ser 152:13-25

Lê S, Josse J, Husson F (2008) FactoMineR : A Package for Multivariate Analysis. J Stat Softw 25:1-18

Lebret K, Fernández MF, Hagman CHC, Rengefors K, Hansson LA (2012) Grazing resistance allows bloom formation and may explain invasion success of Gonyostomum semen. Limnol Oceanogr 57:727-734

Leruste A, Malet N, Munaron D, Derolez V, Hatey E, Collos Y, Wit R De, Bec B (2016) First steps of ecological restoration in Mediterranean lagoons: shifts in phytoplankton communities. Estuar Coast Shelf Sci 180:190-203

Lie AAY, Wong CK, Lam JYC, Liu JH, Yung YK (2011) Changes in the nutrient ratios and phytoplankton community after declines in nutrient concentrations in a semi-enclosed bay in Hong Kong. Mar Environ Res 71:178-188

Litchman E, Klausmeier CA, Schofield OM, Falkowski PG (2007) The role of functional traits and trade-offs in structuring phytoplankton communities: Scaling from cellular to ecosystem level. Ecol Lett 10:1170-1181 
Litchman E, Tezanos Pinto P de, Klausmeier CA, Thomas MK, Yoshiyama K (2010) Linking traits to species diversity and community structure in phytoplankton. Hydrobiologia $653: 15-28$

Lutz R, Jablonski D (1978) Larval bivalve shell morphometry: a new paleoclimatic tool? Sci New Ser 202:51-53

Marie D, Partensky F, Jacquet S, Vaulot D (1997) Enumeration and cell cycle analysis of natural populations of marine picoplankton by flow cytometry using the nucleic acid stain SYBR Green I. Appl Environ Microbiol 63:186-193

Martel A, Hynes TM, BucklandNicks J (1995) Prodissoconch morphology, planktonic shell growth, and site at metamorphosis in Dreissena polymorpha. Can J Zool Rev Can Zool $73: 1835-1844$

Martel AL, Tremblay R, Toupoint N, Olivier F, Myrand B (2014) Veliger Size at Metamorphosis and Temporal Variability in Prodissoconch II Morphometry in the Blue Mussel (Mytilus edulis): Potential Impact on Recruitment. J Shellfish Res 33:443-455

Mazouni N, Deslous-Paoli J, Landrein S (1998) Impact of oyster culture on nutrients and oxygen fluxes in a coastal lagoon. Oceanol Acta 21:845-858

Mazouni N, Gaertner JC, Deslous-Paoli JM (1998) Influence of oyster culture on water column characteristics in a coastal lagoon (Thau, France). Hydrobiologia 373/374:149-156

Mazouni N, Gaertner JC, Deslous-Paoli JM, Landrein S, Geringer d'Oedenberg M (1996) Nutrient and oxygen exchanges at the water-sediment interface in a shellfish farming lagoon (Thau, France). J Exp Mar Bio Ecol 205:91-113

Neveux J, Lantoine F (1993) Spectrofluorometric assay of chlorophylls and phaeopigments using the least squares approximation technique. Deep Sea Res Part I Oceanogr Res Pap 40:1747- 
1765

Nixon SW (1995) Coastal marine eutrophication: A definition, social causes, and future concerns. Ophelia 41:199-219

Oksanen AJ, Blanchet FG, Kindt R, Legendre P, Minchin PR, Hara RBO, Simpson GL, Solymos P, Stevens MHH, Wagner H (2015) Package “vegan” Ordination methods, diversity analysis and other functions for community and vegetation ecologists. R Packag "vegan" version $2,3-0$

Ozkan K, Jeppesen E, Davidson TA, Bjerring R, Johansson LS, Søndergaard M, Lauridsen TL, Svenning J-CC, Özkan K, Jeppesen E, Davidson TA, Bjerring R, Johansson LS, Søndergaard M, Lauridsen TL, Svenning J-CC (2016) Long-Term Trends and Temporal Synchrony in Plankton Richness, Diversity and Biomass Driven by Re-Oligotrophication and Climate across 17 Danish Lakes. Water 8:1-23

Pastoureaud A, Dupuy C, Chrétiennot-Dinet MJ, Lantoine F, Loret P (2003) Red coloration of oysters along the French Atlantic coast during the 1998 winter season: implication of nanoplanktonic cryptophytes. Aquaculture 228:225-235

Pechenik JA (1990) Delayed metamorphosis by larvae of benthic marine invertebrates: Does it occur? Is there a price to pay? Ophelia 32:63-94

Pechenik J a (1999) On the advantages and disadvantages of larval stages in benthic marine invertebrate life cycles. Mar Ecol Prog Ser 177:269-297

Pechenik JA (2006) Larval experience and latent effects - Metamorphosis is not a new beginning. Integr Comp Biol 46:323-333

Pechenik JA, Heyman WD (1987) Using KCl to determine size at competence for larvae of the marine gastropod Crepidula fornicata (L.). J Exp Mar Bio Ecol 112:27-38 
Pernet F, Barret J, Gall P Le, Corporeau C, Dégremont L, Lagarde F, Pépin JF, Keck N, Gall P Le, Corporeau C, Dégremont L, Lagarde F, Pépin JF, Keck N (2012) Mass mortalities of Pacific oysters Crassostrea gigas reflect infectious diseases and vary with farming practices in the Mediterranean Thau lagoon, France. Aquac Environ Interact 2:215-237

Pernet F, Lagarde F, Jeanné N, Daigle G, Barret J, Gall P Le, Quere C, D’orbcastel ER, Roque d'orbcastel E, Jeannee N, Daigle G, Barret J, Gall P Le, Quere C, Roque d'orbcastel E (2014) Spatial and temporal dynamics of mass mortalities in oysters is influenced by energetic reserves and food quality. PLoS One 9:e88469

Petton B, Boudry P, Alunno-bruscia M, Pernet F (2015) Factors influencing disease-induced mortality of Pacific oysters Crassostrea gigas. Aquac Environ Interact 6:205-222

Petton B, Bruto M, James A, Labreuche Y, Alunno-Bruscia M, Roux F Le (2015) Crassostrea gigas mortality in France: the usual suspect, a herpes virus, may not be the killer in this polymicrobial opportunistic disease. Front Microbiol 6:1-10

Pineda J, Starczak V, Stueckle TA (2006) Timing of successful settlement: Demonstration of a recruitment window in the barnacle Semibalanus balanoides. Mar Ecol Prog Ser 320:233237

Pouvreau S (2015) Observer, analyser et gérer la variabilité de la reproduction et du recrutement de l'huître creuse en France : Le Réseau Velyger, Rapport annuel 2016. R.INT.BREST RBE/PFOM/PI 2017-1. 55p. http://archimer.ifremer.fr/doc/00334/44533/.

Qiu JW, Tremblay R, Bourget E (2002) Ontogenetic changes in hyposaline tolerance in the mussels Mytilus edulis and M. trossulus: Implications for distribution. Mar Ecol Prog Ser 228:143-152

Rayssac N, Pernet F, Lacasse O, Tremblay R (2010) Temperature effect on survival, growth, and 
triacylglycerol content during the early ontogeny of Mytilus edulis and M. Trossulus. Mar Ecol Prog Ser 417:183-191

REPHY - French Observation and Monitoring program for Phytoplankton and Hydrology (2017) REPHY dataset - French Observation and Monitoring program for Phytoplankton and Hydrology in coastal waters. 1987-2016 Metropolitan data. SEANOE. http://doi.org/10.17882/47248.

Rico-Villa B, Bernard I, Robert R, Pouvreau S (2010) A Dynamic Energy Budget (DEB) growth model for Pacific oyster larvae, Crassostrea gigas. Aquaculture 305:84-94

Saeck EA, O’Brien KR, Weber TR, Burford MA (2013) Changes to chronic nitrogen loading from sewage discharges modify standing stocks of coastal phytoplankton. Mar Pollut Bull 71:159-167

Sherr EB, Caron DA, Sherr BF (1993) Staining of heterotrophic protists for visualization via epifluorescence microscopy. Handbook of methods in aquatic microbial ecology. In: Lewis Publishers, Boca Raton, Florida, p 213-227

Siegel S, Castellan JNJ (1988) Non-Parametric Statistics for the behavioural Sciences. In: MacGraw Hill Int. New-York, p 213-214.

Sik Lee Y, Seiki T, Mukai T, Takimoto K, Okada M (1996) Seasonal Variation of Micro-, Nano, and Picophytoplankton in Hiroshima Bay. J Japan Soc Water Environ 19:405-411

Sitran R, Bergamasco A, Decembrini F, Guglielmo L (2009) Microzooplankton (tintinnid ciliates) diversity: Coastal community structure and driving mechanisms in the southern Tyrrhenian Sea (Western Mediterranean). J Plankton Res 31:153-170

Smith VH, Schindler DW (2009) Eutrophication science: where do we go from here? Trends Ecol Evol 24:201-207 
Souchu P, Vaquer A, Collos Y, Landrein S, Deslous-Paoli JM, Bibent B (2001) Influence of shellfish farming activities on the biogeochemical composition of the water column in Thau lagoon. Mar Ecol Prog Ser sous press:141-152

St-Onge P, Tremblay R, Sevigny J-M (2015) Tracking larvae with molecular markers reveals high relatedness and early seasonal recruitment success in a partially spawning marine bivalve. Oecologia 178:733-746

Thorson G (1950) Reproductive and larval ecology of marine bottom invertebrates. Biol Rev 25:1-45

Toupoint N, Gilmore-Solomon L, Bourque F, Myrand B, Pernet F, Olivier F, Tremblay R (2012) Match/mismatch between the Mytilus edulis larval supply and seston quality: effect on recruitment. Ecology 93:1922-1934

Tournier H, Pichot Y (1987) Répartition de la chlorophylle $a$ dans l'etang de thau : richesse nutritive pour les mollusques d'élevage. Rev des Trav l'Institut des Pech Marit 49:13-24

Ubertini M, Lagarde F, Mortreux S, Gall P Le, Chiantella C, Fiandrino A, Bernard I, Pouvreau S, Roque d'Orbcastel E, D’Orbcastel ER (2017) Gametogenesis, spawning behavior and larval abundance of the Pacific oyster Crassostrea gigas in the Thau lagoon: Evidence of an environment-dependent strategy. Aquaculture 473:51-61

Utermöhl von H (1931) Neue Wege in der quantitativen Erfassung des Planktons. (Mit besondere Beriicksichtigung des Ultraplanktons). Verh Int Verein Theor Angew Limnol 5:567-595

Vethaak AD, Davies IM, Thain JE, Gubbins MJ, Martinez-Gomez C, Robinson CD, Moffat CF, Burgeot T, Maes T, Wosniok W, Giltrap M, Lang T, Hylland K (2017) Integrated indicator framework and methodology for monitoring and assessment of hazardous substances and 
their effects in the marine environment. Mar Environ Res 124:11-20

Yamagishi T, Kai A, Kawai H (2012) Trichocyst ribbons of a cryptomonads are constituted of homologs of R-body proteins produced by the intracellular parasitic bacterium of Paramecium. J Mol Evol 74:147-157

Yanagi T (2015) Estuaries of the World, Eutrophication and Oligotrophication in Japanese Estuaries. The present and future tasks, Springer.

Yoo Y Du, Seong KA, Jeong HJ, Yih W, Rho JR, Nam SW, Kim HS (2017) Mixotrophy in the marine red-tide cryptophyte Teleaulax amphioxeia and ingestion and grazing impact of cryptophytes on natural populations of bacteria in Korean coastal waters. Harmful Algae $68: 105-117$

Zardus JD, Martel AL (2002) Phylum Mollusca: Bivalvia. Atlas Mar Invertebr larvae:289-325 
Table 1: Variables characterizing interactions between the environment and larvae. Each environmental variable was averaged over a 2 -week period preceding the retrieval of the collectors to characterize the environment for metamorphosis.

\begin{tabular}{|c|c|c|c|}
\hline Variables & Description & Unity & Abbreviation \\
\hline $\begin{array}{l}\text { Target variables } \\
\text { prodissoconch II height } \\
\text { oyster spat } \\
\text { pediveligers }\end{array}$ & $\begin{array}{l}\text { measure } \\
\text { abundance } \\
\text { abundance }\end{array}$ & $\begin{array}{l}\quad \mu \mathrm{m} \\
\text { ind. } \mathrm{dm}^{-2} \\
\text { ind. } \mathrm{dm}^{-2}\end{array}$ & $\begin{array}{l}\text { P2 size } \\
\text { oyster spat } \\
\text { pedi }\end{array}$ \\
\hline $\begin{array}{l}\text { Environmental variables } \\
\text { spat / pediveliger survival } \\
\text { oxygen concentration } \\
\text { temperature } \\
\text { salinity } \\
\text { bacteria } \\
\text { total picoeukaryotes } \\
\text { total picocyanophyceae } \\
\text { nanophytoplankton } \\
\text { cryptophytes } \\
\text { heterotrophic flagellates } \\
\text { ciliates } \\
\text { tintinnids } \\
\text { diatoms } \\
\text { dinoflagellates } \\
\text { total chlorophyll } a \\
\text { picophytoplankton } \\
\text { nanophytoplankton } \\
\text { micro-phytoplankton larger } \\
\text { than } 20 \mu \text { m }\end{array}$ & $\begin{array}{l}\text { ratio of oyster spat to pediveliger } \\
\text { abundance } \\
\text { daily average } \\
\text { daily average } \\
\text { daily average } \\
\text { abundance } \\
\text { abundance } \\
\text { abundance } \\
\text { abundance } \\
\text { abundance } \\
\text { abundance } \\
\text { abundance } \\
\text { abundance } \\
\text { abundance } \\
\text { abundance } \\
\text { biomass } \\
\text { biomass } \\
\text { biomass } \\
\text { biomass }\end{array}$ & 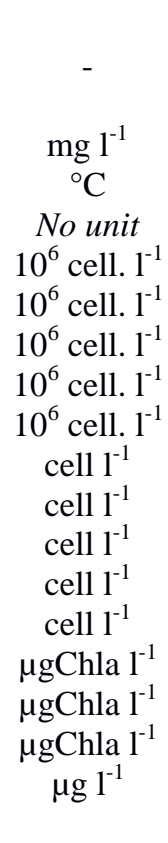 & $\begin{array}{l}\text { metamorphosis survival } \\
\text { oxygen } \\
\text { temperature } \\
\text { salinity } \\
\text { bacteria }^{\mathrm{A}} \\
\text { peuk }^{\mathrm{A}} \\
\text { cyan }^{\mathrm{A}} \\
\text { nano }^{\mathrm{A}} \\
\text { crypto }^{\mathrm{A}} \\
\text { hf }^{\mathrm{A}} \\
\text { ciliates }^{\mathrm{A}} \\
\text { tintinnids }^{\mathrm{A}} \\
\text { diatoms }^{\mathrm{A}} \\
\text { dinoflagellates }^{\mathrm{A}} \\
\text { Total_chlo_a }^{B} \\
\text { pico }^{B} \\
\text { nano }^{B} \\
\text { microphyto }^{B}\end{array}$ \\
\hline
\end{tabular}


Table 2: Analysis of variance of the linear regression between the survival after metamorphosis and prodissoconch II size. Significant values are in bold.

\begin{tabular}{|cccccc|}
\hline Anova & \multicolumn{1}{c|}{$\mid$} & & \\
\hline Response: PII size & Df & Sum Sq & Mean Sq & F & p \\
Survival after metamorphosis & 1 & 47975 & 47975 & 75.9 & $<$ 2.2e-16 \\
Residuals & 379 & 239600 & 632 & & \\
\hline
\end{tabular}

\begin{tabular}{|ccccc|}
\hline \multicolumn{5}{|c|}{ Linear model: P2 size Survival after metamorphosis } \\
\hline Coefficients & Estimate & Std. Error & T & p \\
Intercept & $\mathbf{2 5 4 . 7}$ & 1.817 & 140.237 & $<\mathbf{2 e - 1 6} * * *$ \\
Survival after metamorphosis & $\mathbf{- 4 0 . 9 4 7}$ & 4.700 & -8.71 & $<\mathbf{2 e - 1 6} * * *$ \\
& & & & \\
Residual standard error & & 25.14 on 379 degrees of freedom \\
Multiple R-squared: $\mathbf{0 . 1 6 6 8}$ & Adjusted R-squared: 0.1646 \\
F: 75.89 on 1 and 379 DF & \multicolumn{3}{c}{$\mathbf{p}<\mathbf{2 . 2 e - 1 6}$} \\
\hline
\end{tabular}


Figure captions

Figure 1: (a) The Mediterranean Thau lagoon in France and (b) sampling sites in Thau lagoon. The five sampling sites where benthic Pacific oyster larvae and juvenile abundances were monitored are (Marseillan, green cross; Meze_osfz, cyan diamond; Bouzigues, black circle; and Listel, blue cross). Red circles show the location of the hydrological and plankton sampling sites. Grey boxes indicate the location of shellfish farms.

Figure 2: The breeding structure carried a set of 3 replicate collectors within the shellfish farming zone. Outside the shellfish farming zone, a mooring system as described by Lagarde et al. (2017) was used. (b) Top view of a collector plate with counting subunits in yellow, in this case: $14 \mathrm{~cm}^{2}$.

Figure 3: Measurement of maximum shell height along maximal $\left(\mathrm{H}-\mathrm{H}^{\prime}\right)$ dorsoventral axis of larvae and juvenile oysters (Bayne 2017) in Thau lagoon. (a) Prodissoconch II and dissoconch shells showing demarcation of the growth line delimiting metamorphosis. (b) Prodissoconch II size $\left(\mathrm{H}-\mathrm{H}^{\prime}=228.9 \mu \mathrm{m}, 2012\right.$ Bouzigues, Replicate 1, middle plate, measurement 8).

Figure 4: Means ( \pm standard error) Pacific oyster spat abundance per $\mathrm{dm}^{2}$ observed at the 5 sampling sites on a west-east gradient (Marseillan, Listel, Meze_osfz, Bouzigues and Balaruc), at two-week intervals throughout the summer in 2012, 2013, and 2014. Juvenile abundances were estimated after four weeks of immersion ( $n=27$ per date $\&$ sampling site). Letters indicate significant groups resulting from the Siegel and Castellan multiple comparisons test $(\mathrm{p} \leq 0.05)$. The squares indicate the main annual recruitment event used to characterize variations in prodissoconch II size. 
Figure 5: Mean ( \pm standard error) of prodissoconch II size as a function of the sampling site on a west-east gradient (Marseillan, Listel, Meze_osfz, Bouzigues and Balaruc) and of the year (2012, 2013 and 2014) during the main annual recruitment events with the associated strength. Letters indicate significant differences according to the two-way-cross permutation Anova, pair-wise tests 'Year x Sampling site' for pairs of levels of the factor 'Sampling site'. Numbers at the bottom of the histograms indicate the number of samples per year and per sampling site.

Figure 6: Principal component analysis (a) Comparison of the broken stick model and eigenvalues, (b) Biplots with correlation circle Dim 1 / Dim 2 of averaged environmental data for a 14 day period preceding the retrieval of the collector (superscript A: abundance, B: biomass), (c) Correlation circle Dim 1 / Dim 3, (d) Correlation circle Dim 2 / Dim 3 and the Site factor per year (e) 2012, (f) 2013, (g) 2014.

Figure 7: (a) Increasing trend in PII size versus year, (b) Daily temperatures during the 2 week metamorphosis period preceding retrieval of the collector (August 13, 2012, August 28, 2013, and August 27, 2014), (c) Significant relationship between PII size and temperature means over the duration of the metamorphosis period. Mid-line: median; box: $25^{\text {th }}$ and $75^{\text {th }}$ percentiles, whiskers: $1.5 \times$ the interquartile range; circle: outliers; line: least square regression; crosses: means.

Figure 8: Relationship between PII size (mean of 10 measurements per circle, 3 replicated plates per collector) with plankton during the metamorphosis period, (a) total chlorophyll- $a$ biomass, (b) micro-phytoplankton biomass, (c) nanophytoplankton biomass, (d) cryptophyte abundance (e) picocyanobacteria abundance (f) tintinnid abundance. Significant values $* \mathrm{p}<0.05$; $* * \mathrm{p}<0.01 ; * * * \mathrm{p}<0.001$ 
Figure 9: Prodissoconch II size (Anova $\mathrm{p}<0.001$ ) as a function of metamorphosis survival expressed in percent ( $\mathrm{n}=333$, censured data $100+$ for over $100 \%$ survival); black line: regression line, red dotted line: $\pm 95 \%$ confidence interval. 


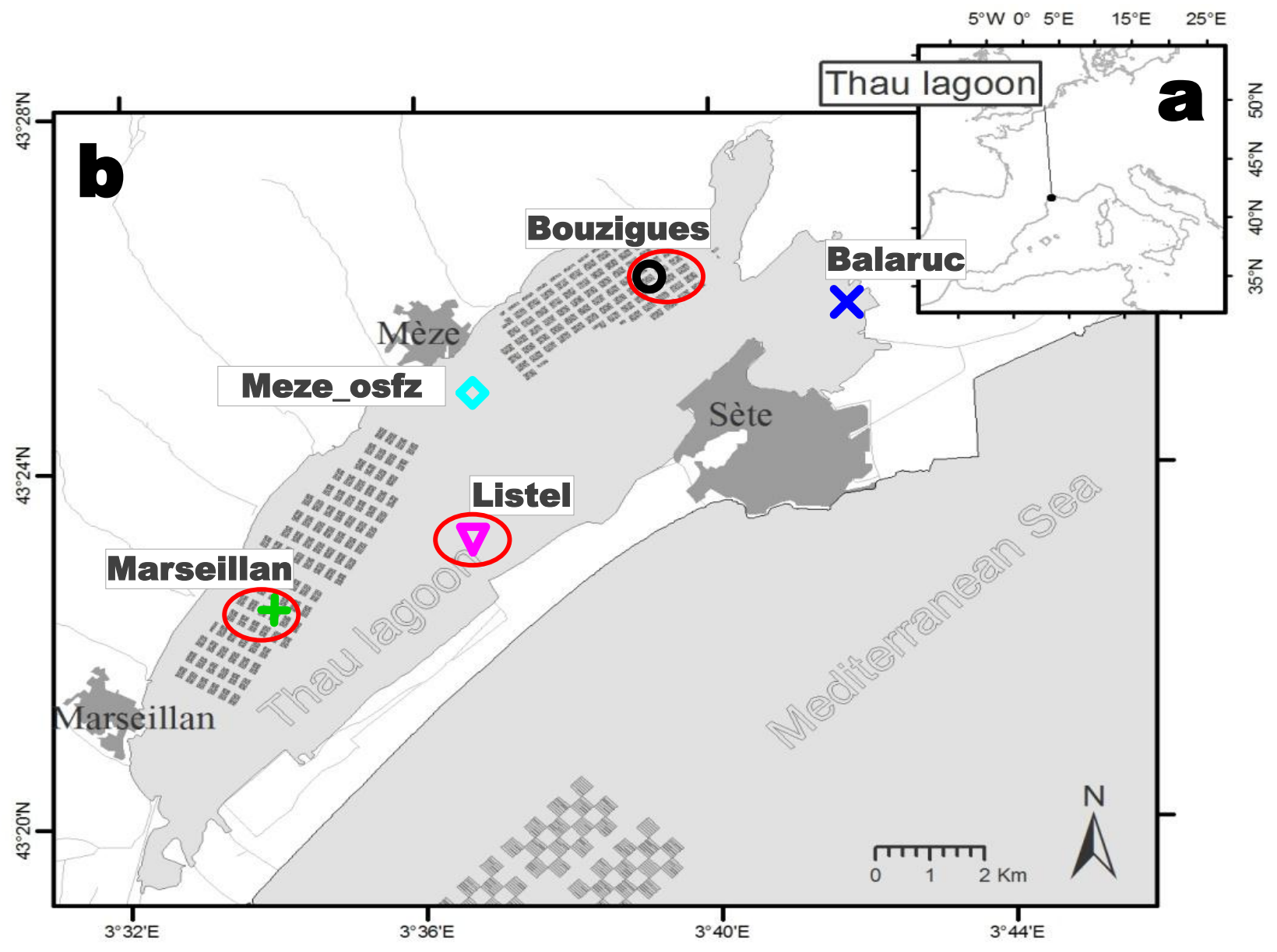

Figure 1 

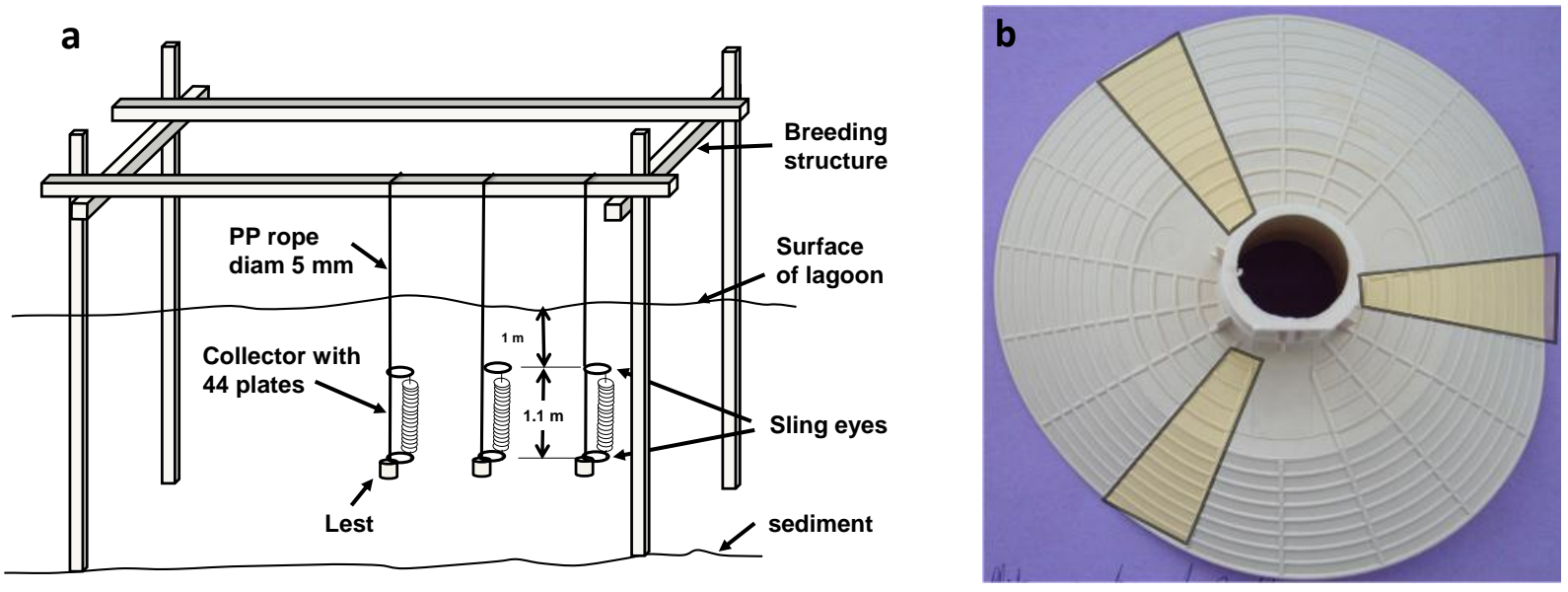

Figure 2 

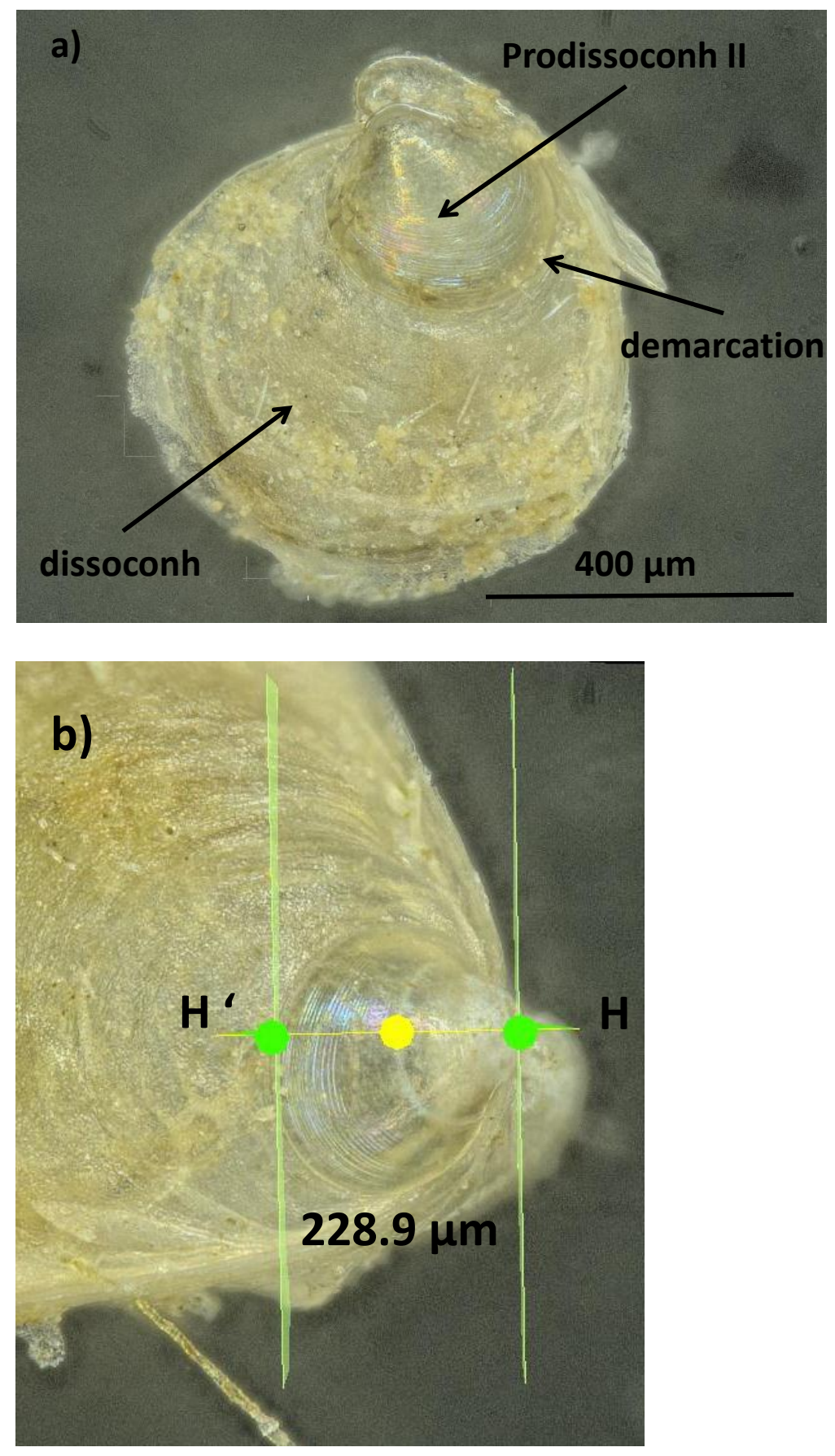

Figure 33 


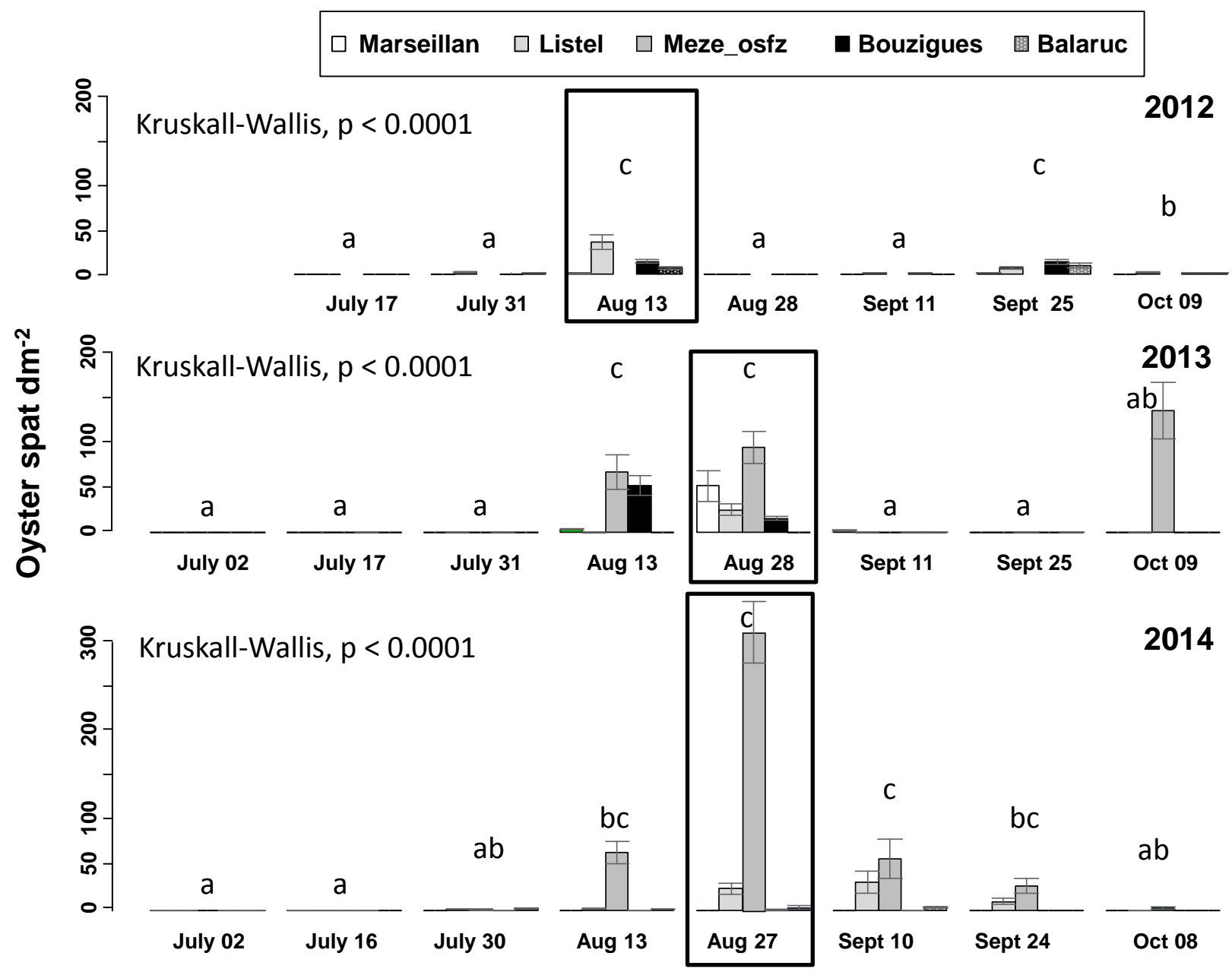

Figure 4 


\begin{tabular}{|lll|}
\hline West side & & East side \\
$\square$ Marseillan $\square$ Listel $\square$ Meze_osfz $\quad \square$ Bouzigues $\quad$ 固 Balaruc
\end{tabular}

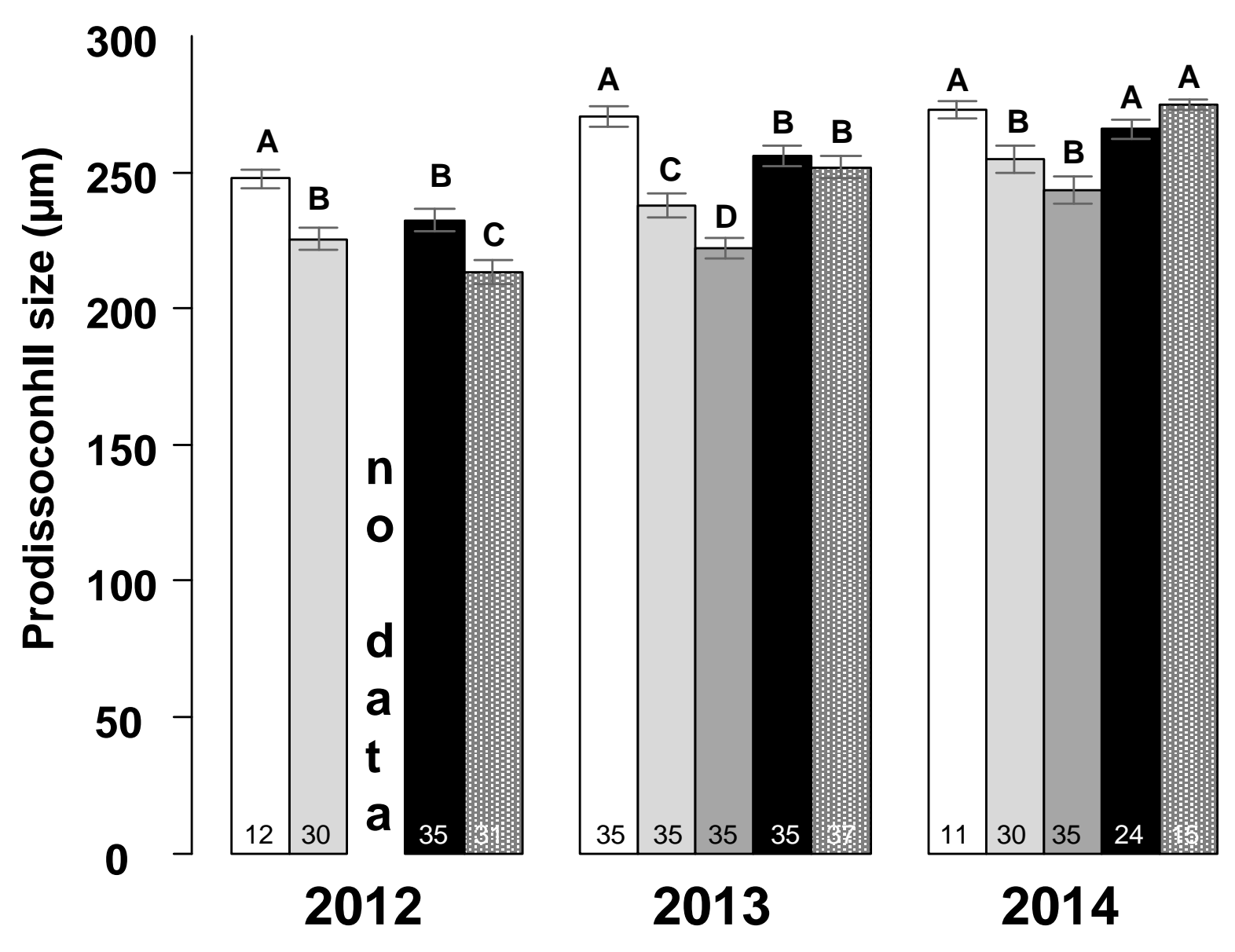

Figure 5 

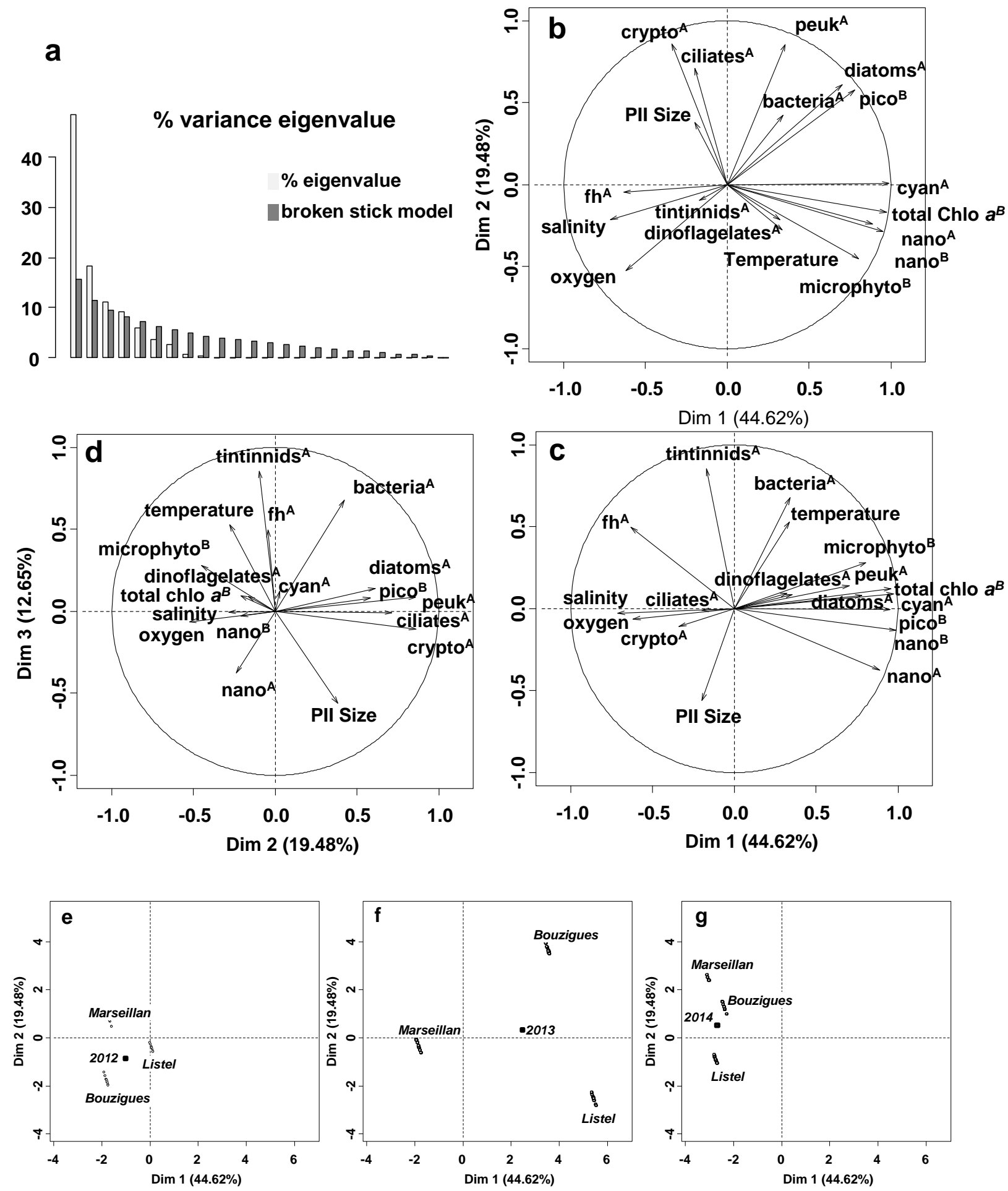

Figure 6 

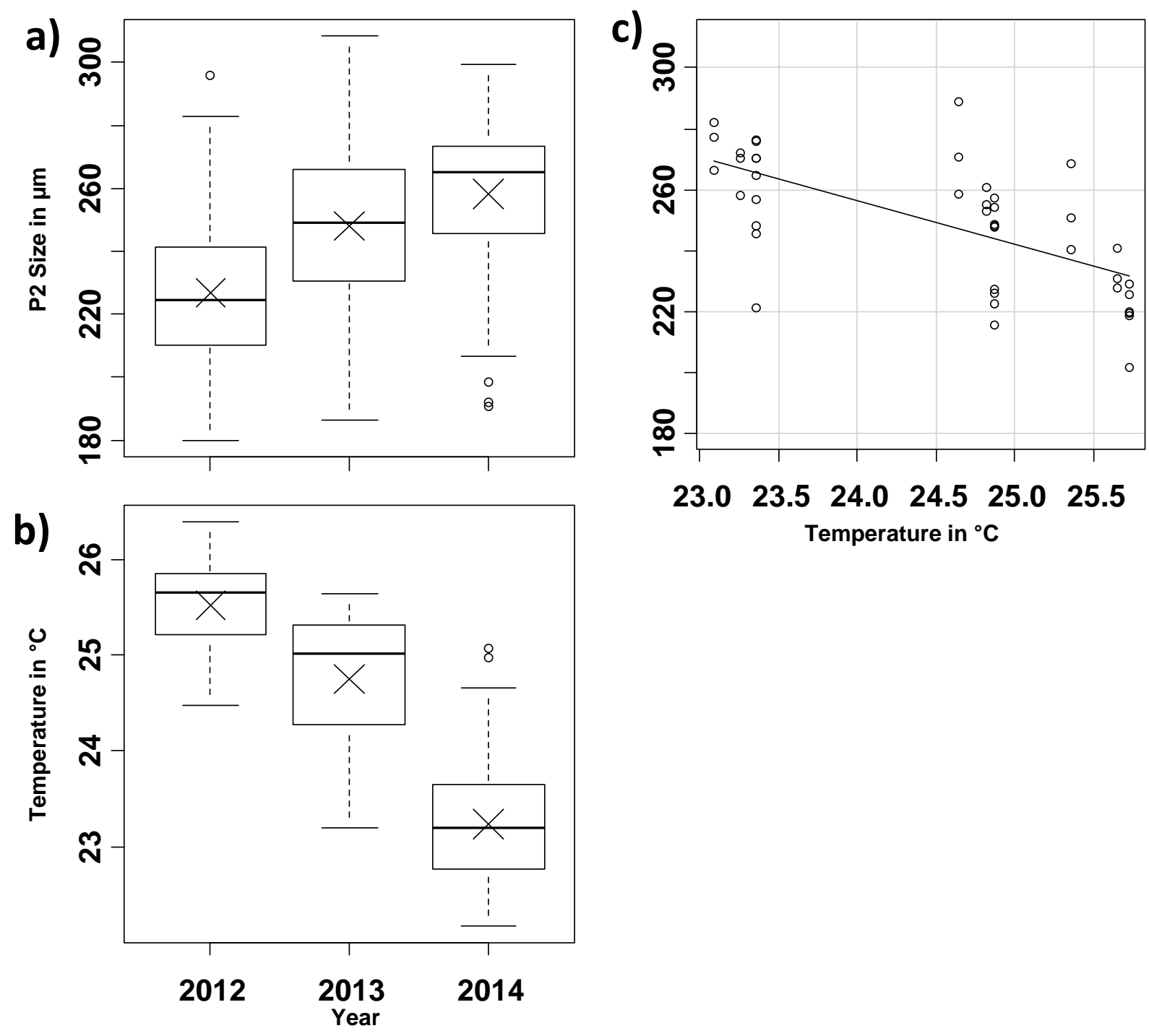

$\begin{array}{llllll}23.0 & 23.5 & 24.0 & 24.5 & 25.0 & 25.5\end{array}$ Temperature in ${ }^{\circ} \mathrm{C}$

Figure 7 

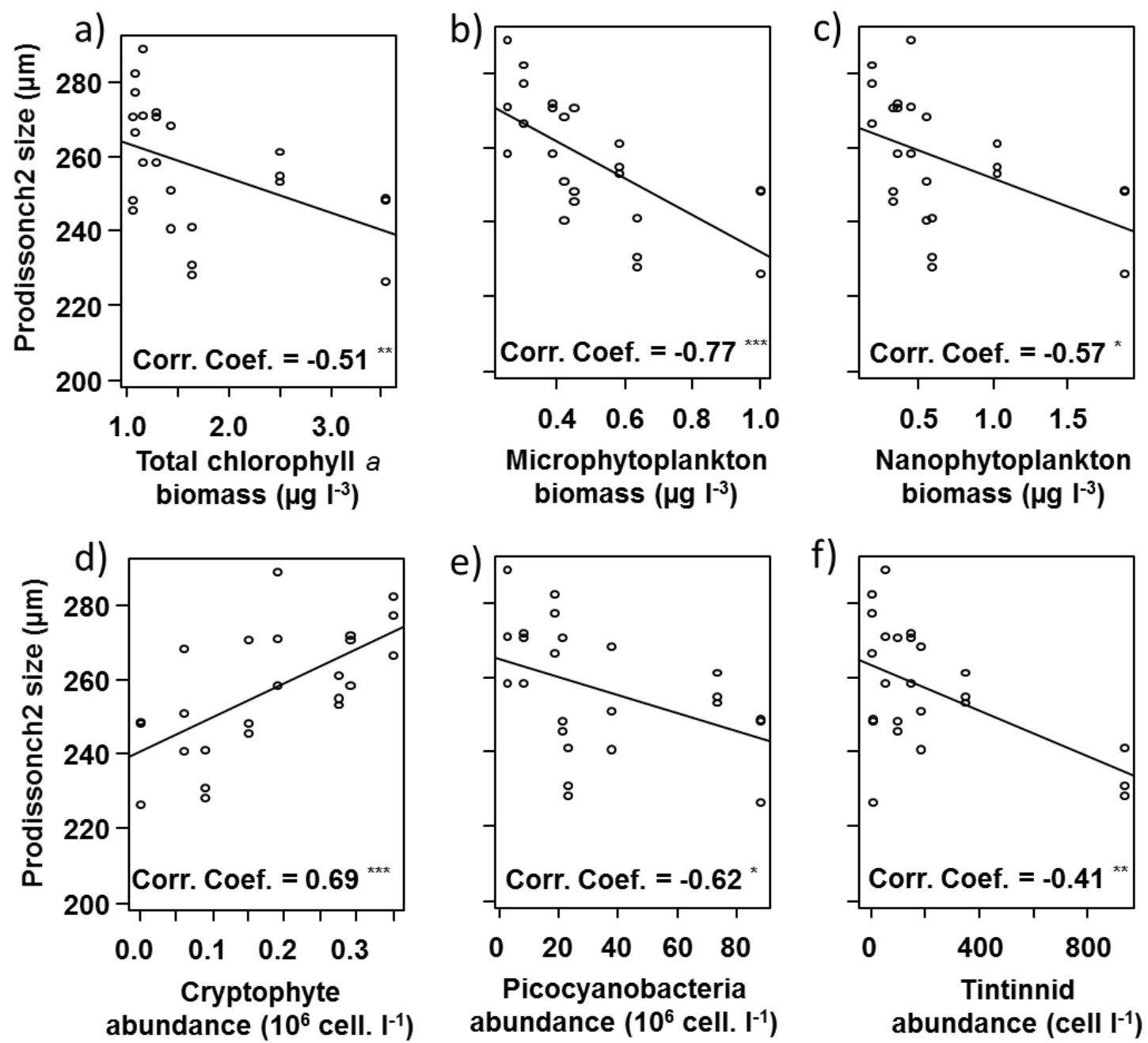

Figure 8 


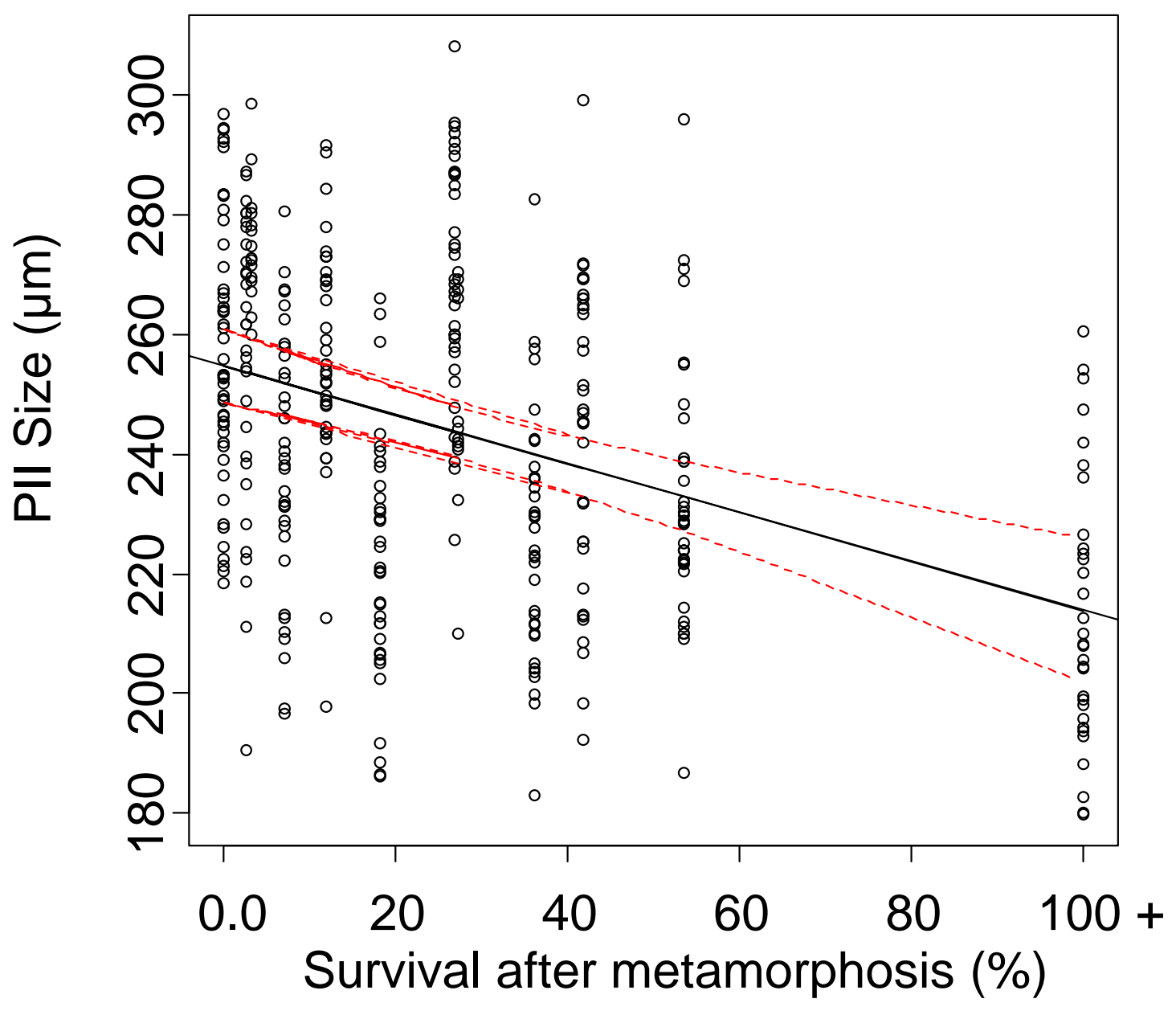

Figure 9 